Bryant University

Bryant Digital Repository

Finance Journal Articles

Finance and Financial Services Faculty Publications and Research

$12-22-2019$

\title{
Does Corporate Social Responsibility Reduce the Costs of High Leverage? Evidence from Capital Structure and Product Market Interactions
}

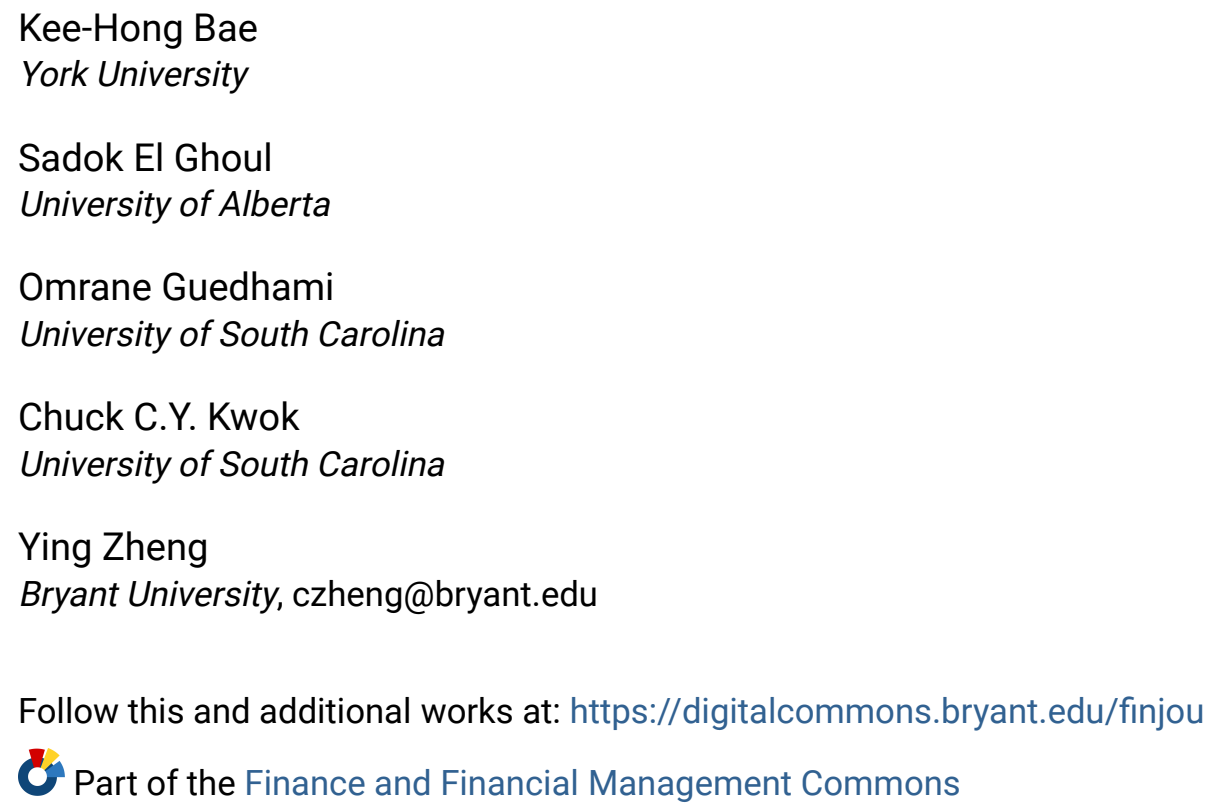

\section{Recommended Citation}

Bae, Kee-Hong; El Ghoul, Sadok; Guedhami, Omrane; Kwok, Chuck C.Y.; and Zheng, Ying, "Does Corporate Social Responsibility Reduce the Costs of High Leverage? Evidence from Capital Structure and Product Market Interactions" (2019). Finance Journal Articles. Paper 77. https://digitalcommons.bryant.edu/finjou/77 


\title{
Does Corporate Social Responsibility Reduce the Costs of High Leverage? Evidence from Capital Structure and Product Market Interactions*
}

\author{
Kee-Hong Bae \\ Schulich School of Business, York University, North York, ON M3J 1P3, Canada \\ Sadok El Ghoul \\ University of Alberta, Edmonton, AB T6C 4G9, Canada \\ Omrane Guedhami \\ Moore School of Business, University of South Carolina, Columbia, SC 29208, USA \\ Chuck C.Y. Kwok \\ Moore School of Business, University of South Carolina, Columbia, SC 29208, USA \\ Ying Zheng \\ School of Business, Bryant University, Smithfield, RI 02917, USA
}

\section{Classification code: G32, M14}

Key Words: Corporate Social Responsibility; Costs of High Leverage; Stakeholder Theory of Capital Structure 


\title{
Does corporate social responsibility reduce the costs of high leverage? Evidence from capital structure and product market interactions
}

This version: November 30, 2018

\begin{abstract}
Research on capital structure and product market interactions shows that high leverage is associated with substantial losses in market share due to unfavorable actions by customers and competitors. We examine whether corporate social responsibility (CSR) affects firms' interactions with customers and competitors, and whether it can reduce the costs of high leverage. We find that CSR reduces losses in market share when firms are highly leveraged. By reducing adverse behavior by customers and competitors, CSR helps highly leveraged firms keep customers and guard against rivals' predation. Our results support the stakeholder value maximization view of CSR.

JEL classification: G32, M14
\end{abstract}

Keywords: Corporate social responsibility; Costs of high leverage; Stakeholder theory of capital structure 


\section{Introduction}

Research on capital structure and product market interactions has documented significantly negative effects of high leverage on product market performance (Opler and Titman, 1994; Campello, 2003, 2006). For example, high leverage can lead to substantial losses in market share due to unfavorable actions by customers and competitors. Customers may be reluctant to purchase from highly leveraged firms because these firms may renege on implicit customer contracts by discontinuing product support or reducing product quality (Titman, 1984; Maksimovic and Titman, 1991; Matsa, 2011; Kini, Shenoy, and Subramaniam, 2017). A highly levered firm could also have strong incentives to increase cash flows by cutting customer service costs in order to stave off imminent bankruptcy. Because rational customers recognize there may be incentives for a highly levered firm to change its trade terms, they require lower prices for their purchases, and this results in a reduction in firm value. In other words, high leverage can impose significant ex ante costs on a firm's customers, and these costs can constitute an important component of indirect bankruptcy costs.

Furthermore, competitors may undertake predatory attacks such as capital-intensive promotion activities (e.g., negative advertising campaigns, deep price discounts) against highly leveraged firms. Because these firms face high cost of capital and generally have difficulty raising external funds, they have less ability to withstand attacks from competitors. They can therefore be forced to surrender substantial market share (Telser, 1966; Bolton and Scharfstein, 1990; Chevalier, 1995). ${ }^{1}$

\footnotetext{
${ }^{1}$ In this paper, we follow Freeman (1984) and define stakeholders as "any group or individual who can affect or is affected by the achievement of the organization's objectives" (Freeman, 1984, p. 40). Accordingly, we classify both customers and competitors as stakeholders.
} 
While the detrimental effects of high leverage on product market performance are well documented, we know little about the mechanisms that can mitigate the costs. In this paper, we aim to fill this gap in the literature. We argue that corporate social responsibility (CSR) can reduce the negative impact of high leverage on product market performance. Our study offers insights into the potentially important role of CSR in reducing the costs of high leverage due to a firm's conflicts with its stakeholders, such as customers and competitors.

It is well documented in the marketing and economics literatures that socially conscious consumers, when matched with high-CSR firms, are loyal, insensitive to negative information about these firms, and willing to pay a higher price for their products (see the review in Kitzmueller and Shimshack, 2012). Modeling CSR as a product differentiation strategy, Albuquerque, Koskinen, and Zhang (2017) develop a theory that high-CSR firms face less priceelastic demand, and can charge higher prices, ceteris paribus. Thus, these firms' cash flows become less volatile over the business cycle, resulting in higher optimal leverage. We further hypothesize that high-CSR firms can better withstand the negative consequences of high leverage because they face less unfavorable reactions from stakeholders. Overall, we hypothesize that the costs of high leverage are lower for high-CSR firms.

There are at least two reasons for this. First, CSR is associated with a "halo" effect, which increases trust between a firm and its stakeholders and should benefit the firm during tough times (Hong and Liskovich, 2015; Lins, Servaes, and Tamayo, 2017). This halo effect provides a highly leveraged firm with insurance-like protection that can temper negative actions from customers, and reduce competitors' incentives to exploit a highly leveraged firm's weak financial position. For example, customers tend to have a better perception of high-CSR firms, and are more confident they will not break implicit contracts even during times of financial 
stress.

Second, high-CSR firms are perceived as having lower levels of risk (e.g., lower litigation risk) and a wider investor base (Waddock and Graves, 1997; Hong and Kacperczyk, 2009; El Ghoul et al., 2011). ${ }^{2}$ These firms thus have better access to financing and a lower cost of capital (Merton, 1987; Heinkel, Kraus, and Zechner, 2001; Gao, Li, and Ma, 2018), which mitigates the costs imposed by predatory attacks from competitors.

Testing our hypothesis requires measuring two main variables: high leverage cost, and CSR. Following Campello (2006), we use the sensitivity of industry-adjusted sales growth to high leverage as a measure of high leverage cost. A more negative sensitivity represents a higher leverage cost. We employ the Fama-French (1997) 48-industry classification to compute industry-adjusted sales growth, which measures "the firm's sales growth relative to that of its industry rivals in a given year; this roughly gauges a firm's market share growth" (Campello, 2006, p. 148). ${ }^{3}$ We obtain firms' CSR scores from MSCI ESG STATS, which is the most extensive database on firms' CSR practices, and has been widely used in recent finance studies on CSR (e.g., Bae, Kang, and Wang, 2011; El Ghoul et al., 2011; Deng, Kang, and Low, 2013; Servaes and Tamayo, 2013; Di Giuli and Kostovetsky, 2014; Krüger, 2015; Hong and Liskovich, 2015; Jung et al., 2016; Lins et al., 2017).

Using a sample of 16,390 firm-year observations representing 2,739 U.S. firms over the 1996-2012 period, we find that CSR mitigates the costs of high leverage. Specifically, a 1-

\footnotetext{
${ }^{2}$ Waddock and Graves (1997) argue that firms attempting to shift costs to external stakeholders through socially irresponsible actions face a higher likelihood of future explicit claims. Hong and Kacperczyk (2009) document that "sin" firms (e.g., tobacco, alcohol, and gaming firms) face a higher risk of litigation.

${ }^{3}$ Our main evidence remains unaffected when we use market share growth instead of sales growth.
} 
standard deviation increase in a firm's relative-to-rival CSR score reduces highly leveraged firms' losses in industry-adjusted sales growth by $1.2 \%$, which is equivalent to recouping $75 \%$ of the costs of high leverage (1.6\%). We also find that CSR strengths reduce the costs of high leverage, and CSR concerns intensify them. Our main evidence is robust to using alternative proxies for CSR and for leverage.

Identifying the causal effect of CSR on high leverage costs is challenging. Both are subject to endogeneity, ${ }^{4}$ and could therefore be driven by unobserved firm-specific factors. For example, firms with deeper pockets tend to invest more in CSR and to better withstand competition while in distress; however, this does not imply that CSR causes better product market performance. Endogeneity could also come from reverse causality: A reduction in sales growth can force firms to incur more debt to cover expenses, and this effect may be somewhat less pronounced for highCSR firms. In our analyses, we mitigate these concerns by using the relative measurement method (Opler and Titman, 1994; Campello, 2003, 2006). Because peer firm performance is beyond a focal firm's control, relative-to-peer measures are less likely to be endogenous. We follow Campello (2006), and measure high leverage costs using long-term debt, which is less sensitive to short-term performance. We also use two-year lagged leverage and CSR variables. In additional analyses, we use 2SLS and system GMM, and introduce the exogenous shock of financial crisis. These endogeneity test results consistently show that CSR reduces high leverage costs.

We next examine whether CSR reduces the costs of high leverage through the customer

\footnotetext{
${ }^{4}$ Previous studies (e.g., Opler and Titman, 1994; Campello, 2006) have addressed endogeneity in the relation between leverage and sales growth. In addition to addressing the endogeneity of the high leverage variable, we tackle the endogeneity of CSR.
} 
channel, the competitor channel, or both. We refer to the costs of high leverage due to unfavorable actions by customers and competitors customer-driven and competitor-driven costs, respectively. We expect a stronger effect of CSR when customer-driven costs are higher-for example, when product specialization is higher, or when highly leveraged firms produce consumer goods. Similarly, we expect the effect of CSR to be more pronounced when competitor-driven costs are higher-for example, when competitors are financially robust (Campello, 2003; Campello and Fluck, 2006), or when highly leveraged firms operate in concentrated industries (Opler and Titman, 1994). Our results are consistent with these predictions, suggesting that the mitigating effects of CSR on the costs of high leverage operate through both the customer and competitor channels.

Our study makes contributions to at least two literatures. First, to the best of our knowledge, we are the first to investigate the role of CSR in the unique setting of capital structure and product market interactions. While prior studies on capital structure and product market performance have focused on the negative consequences of high leverage policies, ${ }^{5}$ ours provides a mechanism to mitigate these effects. Furthermore, our study allows us to identify specific channels through which CSR affects firm value.

In related work, Deng et al. (2013) examine the effect of CSR on firm value in a merger setting, because the merger approval and integration processes are also influenced by various

\footnotetext{
${ }^{5}$ For example, Chevalier (1995) finds that prices fall following leveraged buyouts (LBOs) in local markets where competitors have low leverage, suggesting that low leverage rivals prey on LBO firms. Matsa (2011) finds that highly leveraged supermarket firms tend to degrade their products' quality. Kini et al. (2017) show that firms with higher financial leverage experience greater probability of a product recall, as well as more frequent and severe recalls.
} 
stakeholder groups. Cao, Liang, and Zhan (2018) investigate the effect of adopting CSR proposals on peer firms' CSR practices. Our study builds on and extends their work by identifying how CSR influences two specific stakeholder groups, namely, customers and competitors. We show that CSR reduces the adverse behavior of customers and competitors when firms are highly leveraged. This evidence on the risk management role of CSR improves our understanding of the mechanisms through which CSR influences firm value.

Second, our study contributes to the debate on whether CSR is value-enhancing or valuedestroying. The value-enhancing view holds that CSR increases shareholder welfare by improving firm-stakeholder relationships. Research that substantiates this view has uncovered a range of findings, such as well-governed firms invest more in CSR (Ferrell, Liang, and Renneboog, 2016), firms with higher employee satisfaction command higher stock returns (Edmans, 2011), and stakeholder-oriented firms exhibit greater innovation and long-term performance (Flammer and Kacperczyk, 2016) and benefit from a lower cost of capital (El Ghoul et al., 2011; Gao et al., 2018). Moreover, CSR has been found to improve investors' perceptions of a firm's trustworthiness, and thus mitigate market underreactions to earnings news (Jung et al., 2016), the adoption of close-call CSR proposals increases firm value by improving labor productivity and sales growth (Flammer, 2015), shareholder activism promoting CSR improvements is associated with higher subsequent sales growth and stock returns (Barko, Cremers, and Renneboog, 2017), and high-CSR firms undertake value-enhancing mergers and acquisitions (Deng et al., 2013), and performed better during the 2008-2009 financial crisis (Lins et al., 2017).

In contrast, the value-decreasing view holds that CSR activities are manifestations of agency problems. Studies supporting this view (e.g., Friedman, 1970) find that CSR activities reduce 
shareholder wealth by increasing opportunistic managers' abilities to misuse corporate resources for their private gains (Pagano and Volpin, 2005; Cronqvist et al., 2009; Masulis and Reza, 2015). Using the setting of capital structure and product market interactions, our study contributes to the debate by supporting the value-enhancing view of CSR.

Our study proceeds as follows. Section 2 describes our sample, the main variables, and our empirical design. Section 3 presents the results. Section 4 concludes.

\section{Sample, main variables, and empirical design}

\subsection{Sample construction}

The sample selection process begins with all U.S. firms in Compustat over the 1988-2012 period. For industry classification, we use the Fama-French (1997) 48-industry groups. We omit observations that have negative total assets and sales, missing equity, or a long-term debt-to-asset ratio of less than 0 or greater than 1 . We next eliminate firm-years with asset or sales growth greater than $200 \%$ to control for outliers. We further exclude observations with a missing FamaFrench (1997) 48-industry classification, and observations from financial institutions, utilities, and industries that are not clearly defined (i.e., industries coded "almost nothing"). Based on the resulting sample, we compute the industry-year mean of our main financial variables. To ensure it is not biased toward outliers, we require that each industry-year contain at least four firms. These filters yield 123,667 firm-year observations representing 13,919 firms.

Next, we merge the Compustat sample with data from MSCI ESG STATS (formerly known as KLD STATS), which tracks firms' CSR ratings since 1991. After calculating the industryadjusted CSR scores, we exclude firm-years with missing values for variables in our main regression. The final sample is comprised of an unbalanced panel of 16,390 U.S. firm-year 
observations representing 2,739 firms over the 1996-2012 period. $^{6}$

Table 1 presents the sample distribution by industry and year. Firms belonging to the Business Services (12.31\%), Retail (8.93\%), and Electronic Equipment (7.95\%) categories dominate the sample. Turning to the distribution by year, the number of sample firms is steady, at slightly over 300 per year for the 1996-2002 period, before increasing to 622 in 2004 and 1,600 in 2005. The number of firms per year then remains fairly stable at around 1,600 over 20052012. Changes in the distribution by year are due to increased CSR coverage.

\subsection{Main variables}

\subsubsection{Corporate social responsibility}

MSCI ESG STATS collects information from government agencies, non-governmental organizations, global media publications, annual reports, regulatory filings, proxy statements, and company disclosures to construct firms' CSR ratings. Its coverage has expanded over time. Over the 1991-2000 period, it covered the S\&P 500 and the Domini Social Index. Since 2000, it has covered additional indexes, with the Russell 1000 Index added in 2001, the Large Cap Social Index added in 2002, and both the Russell 2000 Index and the Broad Market Social Index added in 2003.

MSCI ESG STATS tracks seven CSR areas: community, diversity, employee relations, environment, human rights, product characteristics, and corporate governance. Within each area, a value of 0 or 1 is assigned to various strengths or concerns (see Appendix A). For each firm-

\footnotetext{
${ }^{6}$ The human rights area was not covered from 1991 to 1993, and, thus, CSR scores defined in section 2.2 are missing during this period. Because the CSR data for our purposes begin in 1994, and we lag these data two years in the baseline regression, our final sample begins in 1996. Similarly, our sample ends in 2012, because coverage of the human rights area dropped dramatically in 2013 and ceased in 2014.
} 
year, we calculate the scores for each CSR area by subtracting the number of concerns from the number of strengths. We then obtain the firm's raw CSR score, CSR_NET, by summing the scores across all areas except corporate governance. ${ }^{7}$ This simple summation approach is widely used in the literature (El Ghoul et al., 2011; Jiao, 2010; Bae et al., 2011). However, Deng et al. (2013) note that comparing raw CSR scores can be problematic, because the number of strengths and concerns in an area can vary over time. For example, in the employee relations area, the "Health and safety" factor is not available until 2003. To address this issue, we follow Deng et al. (2013), and construct our main CSR measure, CSR, by dividing the raw strength (concern) scores of each area by the maximum number of strengths (concerns) in that area-year, and then taking the difference between the adjusted strength and concern scores for that area. Appendix B provides detailed variable definitions.

\subsection{The costs of high leverage}

Campello (2006) revisits Opler and Titman's (1994) finding that high leverage has a detrimental effect on relative-to-rival product market performance. He shows that, in equilibrium, the negative product market effect of leverage arises only when leverage is sufficiently high. Campello (2006) also finds that excessive indebtedness leads to unfavorable actions by customers and competitors, while moderate indebtedness is associated with improved relative-to-rival sales performance. We follow this line of reasoning, and capture the costs of high leverage using the sensitivity of sales to high leverage. Specifically, we estimate the following model:

\footnotetext{
7 We exclude the corporate governance component to ensure that our CSR measure is not simply a proxy for governance effects. However, our results continue to hold when we include corporate governance, as shown in robustness tests.
} 


$$
\begin{gathered}
S A L E S \_G_{i, t}=a+\lambda_{1} H_{L E V} V_{i, t-2}+\lambda_{2} \text { SIZE }_{i, t}+\sum_{k=1}^{2} \lambda_{3 k} P_{R O F I T} T_{i, t-k}+ \\
\sum_{k=1}^{2} \lambda_{4 k} I_{N V E S T M E N T} T_{i, t-k}+\sum_{k=1}^{2} \lambda_{5 k} \text { SELLEXP }_{i, t-k}+\varepsilon_{i, t},
\end{gathered}
$$

where $i$ indexes firms and $t$ indexes years. Sales growth, SALES_G, is assumed to reflect the actions of customers and competitors. We should observe a decrease in sales growth if customers abandon the firm, or if the firm faces predation by competitors. $H L E V$ is a dummy variable that takes a value of 1 if the firm's long-term debt ratio is in the top three deciles of the overall sample in a given year. We use long-term debt in constructing our high leverage measure in order to mitigate concerns about reverse causality from sales growth to leverage. This is because longterm debt is less likely to be adjusted in response to short-term performance (Campello, 2006). We further attempt to mitigate reverse causality by using a two-year lag between the high leverage measure and sales growth (Campello, 2006). The coefficient on $H L E V, \lambda_{1}$, captures the costs of high leverage, with a more negative value indicating higher costs.

The above model controls for several variables that are correlated with both sales growth and leverage, as their omission would lead to a biased coefficient on HLEV. Our first control is firm size, SIZE, which is equal to the natural logarithm of total assets. Large firms tend to have higher debt capacity. They also tend to be more mature, and to grow at a slower pace. The second control variable is profitability, PROFIT, computed as operating earnings plus depreciation over total assets. High leverage may indicate that a firm cannot generate sufficient revenue to cover expenses. However, it may serve to discipline management (Jensen, 1986) and to increase profitability, which can affect future sales growth through the firm's ability to retain earnings. Our third control variable is capital investment, $I N V$, which is equal to capital expenditures over total assets. While a firm's capital investment depends on its debt burden, it contributes to future sales growth. The final control variable is the ratio of advertising and selling expenses to total 
sales, SELLEXP. Higher selling expenses should be positively related to future sales, but are also correlated with leverage (Chevalier and Scharfstein, 1996). All control variables are winsorized at the $1 \%$ and $99 \%$ levels to mitigate the influence of outliers. The reported $t$-statistics are based on robust standard errors adjusted for clustering at the firm level. Appendix B provides detailed variable definitions.

\subsection{Empirical design}

To examine the effect of CSR on the costs of high leverage, we augment the costs of the high leverage model in Equation (1) with CSR and its interaction with $H L E V$. The regression is as follows:

$$
\begin{gathered}
\text { SALES_G }_{i, t}=b+\beta_{1} \text { CSR }_{i, t-2} \times \operatorname{HLEV}_{i, t-2}+\beta_{2} \operatorname{HLEV}_{i, t-2}+\beta_{3} \operatorname{CSR}_{i, t-2}+\beta_{4} \operatorname{SIZE}_{i, t}+ \\
\sum_{k=1}^{2} \beta_{5 k} \text { PROFIT }_{i, t-k}+\sum_{k=1}^{2} \beta_{6 k} \operatorname{INVESTMENT}_{i, t-k}+\sum_{k=1}^{2} \beta_{7 k} \operatorname{SELLEXP}_{i, t-k} \\
+\varepsilon_{i, t}
\end{gathered}
$$

In (2), $\beta_{1}$ measures the effect of $C S R$ on the costs of high leverage. A positive (negative) value indicates that CSR activities reduce (increase) the costs of high leverage.

One main concern with Equations (1) and (2) is endogeneity bias. First, both CSR and high leverage may reflect unobserved firm characteristics such as corporate culture. Second, deteriorating sales performance could induce a firm to increase debt to cover expenses. To mitigate such concerns, in our main analyses, we adopt the relative measurement method (Opler and Titman, 1994; Campello, 2003, 2006), whereby regression variables are determined in part by other firms' performance. Because it is outside a focal firm's control, relative-to-peer variables are less likely to be endogenous. Specifically, we measure SALES_G, CSR, and the control variables relative to their industry-year means, and we construct $H L E V$ so that a firm is 
considered highly leveraged if its leverage ratio is in the top three deciles in a given year. Moreover, as with $H L E V$, we use a two-year lag between CSR and sales growth.

Table 2 provides descriptive statistics for the key variables (before industry-year adjustments) used in Equations (1) and (2).

\section{Results}

In section 3.1, we provide evidence on the costs of high leverage and the role of CSR in mitigating those costs. Endogeneity concerns are addressed in section 3.2. In section 3.3, we examine the extent to which the effect of CSR on the costs of high leverage is driven by the customer and competitor channels. In section 3.4, we perform additional analyses. Finally, we check the robustness of our results to alternative measures of our key variables in section 3.5.

\subsection{CSR and the costs of high leverage: Main evidence}

In this section, we first establish that high leverage has a negative effect on product market performance as measured by sales growth. We then examine whether CSR can mitigate this negative effect. Model 1 of Table 3 reports the results of estimating Equation (1) using ordinary least squares (OLS). The coefficient on the high leverage dummy is significantly negative, indicating that high leverage is associated with reduced sales growth. Specifically, we find that firms with high leverage experience $1.6 \%$ lower relative-to-rival sales growth than other firms. The magnitude of this estimate is close to the $-1.9 \%$ documented by Campello (2006) for a sample that ends prior to 2000 . Because $90 \%$ of our sample observations correspond to the 2000 2012 period, our findings indicate that the costs of high leverage documented by Campello (2006) have persisted over the last decade.

Models 2 and 3 of Table 3 report the results of estimating Equation (2) using OLS and firm fixed effects, respectively. Model 2 regresses sales growth on CSR $\times H L E V, H L E V, C S R$, and the 
control variables and shows that CSR attenuates the costs of high leverage. Specifically, the coefficient estimate on $C S R \times H L E V$ is significantly positive at 0.025 , suggesting that a 1standard deviation increase in the CSR score (0.48) improves the effects of high leverage on sales growth by $1.2 \%(=0.48 \times 0.025)$. Recall that, in Model 1 , the coefficient estimate on $H L E V$, the proxy for high leverage costs, was -0.016 . The effect of a 1-standard deviation increase in the CSR score is thus economically substantial, reducing the costs of high leverage by $75 \%$ $(0.012 / 0.016)$ on average. Model 3 shows that CSR continues to mitigate the costs of high leverage even after controlling for firm fixed effects. Taken together, these results indicate that high-CSR firms face lower costs of high leverage, consistent with a risk management role of CSR. $^{8}$

Interestingly, we find that the stand-alone CSR variable loads significantly negatively on sales growth. Note that the coefficient on this variable captures the effect of CSR when firms have lower leverage. Its negative coefficient suggests that the risk management benefit of CSR is limited, and indeed outweighed by the costs of CSR investment when firms maintain low leverage. We interpret these findings as evidence that CSR investment is akin to an insurance product. Firms pay insurance premiums in the form of CSR investments when they are financially healthy, and they receive the benefits of CSR insurance when they are in distress.

Next, we examine whether customers and competitors put different weights on positive and negative CSR information for highly leveraged firms. In Model 4 of Table 3, we decompose the

\footnotetext{
${ }^{8}$ Leverage can generate both benefits (e.g., tax shields) and costs (e.g., conflicts with stakeholders). For low-CSR firms with optimal leverage levels, increasing CSR may enable them to increase their leverage to benefit from greater tax shields, while limiting the costs. To test this idea, we examine in an unreported test the impact of CSR on leverage, and find that it is associated with higher leverage.
} 
CSR score into strengths and concerns. CSR strengths represent firms' proactive actions on CSR activities, involving more efficient use of firm resources and reflecting better management quality (Attig et al., 2013). CSR concerns reflect actual negative outcomes such as worker layoffs and pollution (Di Giuli and Kostovetsky, 2014). We find that CSR strengths reduce, and CSR concerns intensify, the costs of high leverage.

However, we note that our results may have alternative interpretations. One interpretation is that spending more on CSR reflects agency problems (Cheng, Hong, and Shue, 2016). But high leverage — due to its disciplining nature — constrains managers by mitigating the free cash flow problem and thus attenuating the negative effect of CSR. This interpretation assumes that governance quality and CSR scores are negatively related.

To examine the relation between governance quality and CSR scores, we use three corporate governance measures: E-index, Institutional Ownership, and Pay-Performance Sensitivity. Eindex is an aggregate index of six provisions: staggered board, limitation on amending bylaws, limitation on amending the charter, supermajority to approve a merger, golden parachute, and poison pill (Bebchuk, Cohen, and Ferrell, 2009). Institutional Ownership measures the extent of stock ownership by institutional investors based on Thomson 13-F data. Pay-Performance Sensitivity (delta) is the CEO's dollar change in wealth associated with a $1 \%$ change in the firm's stock price, calculated using data from the Execucomp database.

In Table 4, we find that the relation between the CSR score and proxies for governance quality are statistically insignificant. In addition, we augment our baseline model (Model 3 of Table 3) with these governance measures and their interactions with $H L E V$. In Table 5, we find that the coefficient estimates on CSR and its interaction with HLEV remain unchanged, suggesting that our results are not entirely explained by corporate governance. 
Another alternative interpretation of our findings is that reduced sales growth in the presence of high leverage reflects efficient downsizing. Because firms with high leverage must submit to the scrutiny of capital markets (Jensen, 1986), highly leveraged firms tend to shut down or otherwise divest themselves of unprofitable product lines. However, even unprofitable product lines can have value for certain customers. For example, low-income individuals may welcome a low-price brand. In this case, a high-CSR firm that cares about social welfare may choose to continue an unprofitable product line, resulting in worse firm performance. Therefore, CSR may hinder efficient downsizing in the presence of high leverage, resulting in less sensitive changes in sales growth. This alternative interpretation predicts that, by impeding efficient downsizing, CSR negatively affects the performance of highly leveraged firms. However, contrary to this prediction, we find, in untabulated results, that CSR helps highly leveraged firms realize higher stock returns and improve operating performance. This suggest that, rather than negatively affecting firm performance by impeding efficient downsizing, CSR positively affects performance by reducing the costs of high leverage.

\subsection{Endogeneity}

Our main results thus far have shown that CSR reduces the costs of high leverage. However, this evidence is subject to potential endogeneity problems that may arise from the $H L E V$ and $C S R$ variables. We mitigate endogeneity concerns in several ways: 1) We construct $H L E V$ using long-term debt, which is less subject to adjustment in response to short-term performance, 2) we use two-period lags between sales growth and both CSR and HLEV, and 3) we use relative-topeer variables, which are unlikely to be under focal firms' control, and are thus less likely to be endogenous. Nevertheless, to further mitigate these concerns, we use 2SLS and system GMM, and we introduce the exogenous shock of financial crisis in additional analyses. 
We use two instruments for CSR: 1) BLUE (following Deng et al., 2013), which is a dummy variable equal to 1 if a firm is headquartered in a Democratic state, and 0 otherwise, and 2) oneyear lagged CSR. We expect these instruments to have a positive effect on CSR, because "blue companies" are more likely to "go green" (Di Giuli and Kostovetsky, 2014), and firms' CSR policies tend to be sticky. To instrument high leverage, we use one- and two-year lagged values of $H L E V$, in the spirit of Campello (2003).

We begin by sequentially considering the endogeneity of $H L E V$ and $C S R$. We obtain fitted values of high leverage by regressing $H L E V$ on the control variables and the two instruments for $H L E V$. We obtain fitted values of CSR by regressing CSR on $H L E V$, the control variables, and the two instruments for CSR. The first-stage regression results are reported in Models 1 and 2 of Table 6. Consistent with our predictions, the instruments for CSR and high leverage load positively on CSR and HLEV, respectively. Importantly, the $F$-statistics are much greater than the threshold value of 10 , which indicates that the instruments likely satisfy the relevance condition.

Models 3 and 4 of Table 6 report the second-stage results. In Model 3, we replace our original $H L E V$ values with the fitted values to determine whether high leverage continues to be costly after accounting for possible endogeneity in $H L E V$. We find that the coefficient on $H L E V$ carries the same magnitude and significance as those in Table 3. In Model 4, we replace the original CSR values with the fitted values to check whether the beneficial role of CSR holds. In Model 5, we consider the potential endogeneity of $H L E V$ and $C S R$ simultaneously. ${ }^{9}$ Both models

\footnotetext{
${ }^{9}$ Because CSR, HLEV , and their interaction term are endogenous in Model 5, we estimate three first-stage regressions, and compute the fitted values for $C S R, H L E V$, and their interaction term. The untabulated first-stage regression results have similar $F$-statistics, which suggests that the relevance of the CSR and HLEV instruments continues to hold.
} 
support the view that CSR mitigates the costs of high leverage.

Note that, in Models 3 to 5 , we test the exogeneity of the instruments by regressing the residuals of the 2SLS models on the instruments and control variables. The $F$-statistics show that the instruments are jointly insignificant in these regressions, which implies that the null hypothesis of no correlation between the residuals and instruments cannot be rejected. We also perform $J$-tests of over-identifying restrictions. The $p$-values on the $J$-statistics are all larger than $10 \%$, suggesting that the instruments are exogenous. Taken together, the results of the $2 \mathrm{SLS}$ models show that our main findings are robust to endogeneity.

Next, we use the system GMM approach developed by Blundell and Bond (1998), and add one-year lagged sales growth, SALES_G $G_{t-1}$, as an independent variable. Model 6 of Table 6 reports the results for the costs of high leverage, Model 7 assumes that only the CSR variable is endogenous, and Model 8 assumes that both the CSR and $H L E V$ variables are endogenous. We continue to find that high leverage is costly and negatively related to CSR at the $1 \%$ level or better, with the Sargan test and the Hansen test of over-identification supporting the validity of the instruments. The results lend further support to our main finding that CSR reduces the costs of high leverage.

Last, we test the effects of the 2008-2009 global financial crisis. Our test is structured as follows. A firm establishes its CSR policy two years before the exogenous shock (i.e., financial crisis). Because the firm's CSR is set prior to the shock, it is unlikely to be affected by it. However, the shock can influence the costs of high leverage. The unexpected tightening of liquidity that occurs during the financial crisis can threaten the survival of highly leveraged firms, inducing stronger reactions from stakeholders and increasing high leverage costs. Consequently, we expect the effect of CSR to be more pronounced during the 2008-2009 crisis 
period.

To test this conjecture, we follow Lins, Volpin, and Wagner (2013), and define 2008 and 2009 as the financial crisis period (FINANCIAL CRISIS). We include additional interaction terms between FINANCIAL CRISIS, CSR, and HLEV. Table 7 reports the results. Consistent with our expectation, we find that the coefficient on FINANCIAL CRISIS $\times C S R \times H L E V$ is positive and statistically significant, indicating that the effects of CSR intensified during the 2008-2009 financial crisis. This finding further mitigates endogeneity concerns.

Although we tackle potential endogeneity using different approaches, we cannot completely rule out this issue. In particular, high leverage itself is likely to be endogenously determined by firm- and industry-level characteristics in a way that is consistent with firm value maximization. In other words, it is possible that, for some firms, high leverage is not a cost, but an outcome of a trade-off that reflects both demand and supply considerations. The IV and GMM estimations above may not fully resolve this endogeneity issue, because sales growth can be directly affected by political leaning (through policies). The financial crisis analysis may help partially mitigate this concern, because the exogenous shock can break the equilibrium leverage, rather than treating the "cost of high leverage" as given.

\subsection{Channels through which CSR reduces the costs of high leverage}

The analyses so far have presented evidence on the effect of CSR on the costs of high leverage. The literature shows that customers and competitors each contribute to a decline in the performance of highly leveraged firms. In this subsection, we test whether this finding extends to our setting - that is, whether the effect of CSR on high leverage costs operates through both customers and competitors.

\subsubsection{Customer channel}


If CSR reduces high leverage costs driven by customers, the effect of CSR should be stronger when customer-driven costs are higher. Research shows these costs are higher under higher product specificity (Opler and Titman, 1994). When a customer purchases a specialized product, a greater portion of the price paid is for implicit claims, such as future servicing. However, because highly leveraged firms are likely to break implicit customer contracts, customers have incentives to avoid high-specificity products.

We use two proxies for the degree of product specificity. First, following Titman and Wessels (1988), we use R\&D expenditures. Following Opler and Titman (1994), we classify a firm as a high- (low-) R\&D intensity firm if its R\&D-to-sales ratio is greater (smaller) than $0.1 \%$ two years before the base year (Opler and Titman, 1994). We treat missing R\&D as zero because firms that do not report their expenditures tend not to be engaged in those activities. High-R\&D expenditures suggest a firm is likely to produce more specialized products. Second, we use product differentiation. Customer-driven costs are also likely to be higher for firms that produce differentiated goods or services than for firms that produce standardized goods. This is because differentiated products or services are associated with implicit claims. To classify goods as standardized versus differentiated, we follow Giannetti, Burkart, and Ellingsen (2011) and Rauch (1999), and divide the sample into industries with standardized or differentiated goods or services. ${ }^{10}$

Table 8 presents the results. Models 1 and 2 show that the coefficient on $C S R \times H L E V$ is

\footnotetext{
${ }^{10}$ According to Giannetti et al. (2011) and Rauch (1999), industries with differentiated goods or services have twodigit SIC codes: 25, 27, 30, 32, 34, 35, 36, 37, 38, 39, 41, 42, 44, 45, 47, 48, 49, 50, 51, 52, 53, 54, 55, 56, 57, 59, $61,64,65,73,75,78$, and 79, while industries with standardized goods have two-digit SIC codes: 12, 14, 20, 22, 23, 24, 26, 28, 29, 31, and 33 .
} 
significantly positive at 0.035 for firms with high $R \& D$ intensity, but insignificantly negative at 0.003 for firms with low R\&D intensity. Models 3 and 4 show that the coefficient on $C S R \times H L E V$ is significantly positive at 0.032 for the differentiated product or service subsample, but is insignificantly positive at 0.009 for the standardized product subsample. These results imply that CSR's attenuation of customer-driven leverage costs is more pronounced for firms with higher product specificity.

The mitigating effect of CSR on high leverage costs is also likely to be stronger when customers are more sensitive to firms' CSR activities. Lev, Petrovits, and Radhakrishnan (2010) argue that corporate charitable contributions are more likely to influence sales for firms producing consumer rather than industrial goods. While consumer purchases are influenced by social forces and psychological factors, industrial purchases tend to be more formalized and to follow well-defined procedures (Corey, 1991). Therefore, a firm's image is likely to play a more important role for consumers than for industrial buyers. Building on this argument, we predict that customers of consumer goods will be more sensitive to the CSR activities of highly leveraged firms. We follow the methodology of Lev et al. (2010) in defining high- and lowcustomer sensitivity industries. ${ }^{11}$

Models 5 and 6 of Table 8 report the results. We find, consistent with Lev et al. (2010), that the influence of CSR is strong and significant for firms in high-customer sensitivity industries,

\footnotetext{
${ }^{11}$ According to Lev et al. (2010), high-customer sensitivity industries are those with four-digit SIC code ranges: [0,999], [2000,2399], [2500,2599], [2700,2799], [2830,2869], [3000,3219], [3420,3429], 3523, [3600,3669], [3700,3719], 3751, [3850,3879], [3880,3999], 4813, [4830,4899], [5000,5079], [5090,5099], [5130,5159], [5220,5999], [6000,6999], [7000,7299], and [7400,9999]. The remaining industries are classified as low-customer sensitivity industries.
} 
but not for those in low-customer sensitivity industries.

To summarize, we find that that CSR reduces high leverage costs for firms in which customer-driven costs are likely to be high, particularly for those that produce high-specificity products and consumer goods.

\subsubsection{Competitor channel}

If CSR reduces the high leverage costs driven by competitors, the effect of CSR should be stronger when competitor-driven costs are higher. We expect competitor-driven costs to be high when highly leveraged firms face financially robust competitors. The rationale is that financially healthy competitors can afford to charge lower prices in an attempt to drive a highly leveraged firm out of the market (Campello, 2003; Campello and Fluck, 2006). Following prior research, we proxy for the financial condition of a firm's competitors by using the industry-average level of debt. We classify an industry as a high- (low-) debt industry if its average long-term debt ratio is above (below) the overall sample median two years before the base year. We also expect competitor-driven sales losses to be more severe in highly concentrated industries where strategic interactions among competitors are strong (Opler and Titman, 1994). Concentration can proxy for the gains associated with driving out a weakened competitor (Bolton and Scharfstein, 1990). For example, competitors can benefit by raising share prices after bankruptcy announcements in concentrated industries (Lang and Stulz, 1992). To measure industry concentration, we use the four-firm concentration ratio $(F F C)$ (Opler and Titman, 1994) and the Herfindahl-Hirschman index $(H H I)$. We classify an industry as highly (less) concentrated if its FFC is above (below) 0.4 (Opler and Titman, 1994) or its $H H I$ is above (below) the overall sample median two years before the base year.

Table 9 presents the results. In Models 1 and 2, we partition the sample by industry debt 
level. Consistent with our predictions, we find that firms from financially robust industries observe a more pronounced effect of CSR on high leverage costs. Specifically, the coefficient on $C S R \times H L E V$ is as large as 0.035 with a $t$-statistic of 2.60 for highly leveraged firms that face financially robust competitors, while it is only 0.010 with a $t$-statistic of 0.86 for firms that face weaker competitors.

Models 3 and 4 report the results for the subsamples partitioned by $F F C$, and Models 5 and 6 report them for the subsamples partitioned by $H H I$. We find that the coefficients on $C S R \times H L E V$ are positive and significant for firms in industries with high concentrations, while they are insignificant for firms in industries with low concentrations. Taken together, these results suggest that the mitigating effect of CSR on high leverage costs also operates through the competitor channel. ${ }^{12}$

\subsection{Additional analyses}

We perform two additional analyses. First, we test whether the role of CSR in reducing high leverage is more important for loss-making firms. Second, we explore which CSR dimensions drive our results.

\subsubsection{The costs of high leverage for loss-making firms}

In this section, we propose that high leverage is more costly for unprofitable firms.

\footnotetext{
${ }^{12}$ While we find evidence supporting both the customer and competitor channels, they are studied in isolation. We use subsample tests to examine the channel effects. In the customer channel tests, our subsamples are based on firm R\&D intensity, product differentiation, and customer sensitivity. In the competitor channel tests, our subsamples are based on industry debt level, the four-firm concentration ratio, and the Herfindahl-Hirschman index. To test the joint effects of the customer and competitor channels, we conduct tests based on subsamples sorted on two dimensions (i.e., four subsamples). The tests seem to lack power due to small sample sizes, however, and the results indicate that neither channel dominates the other.
} 
Stakeholders may not react to high leverage as long as the firm is profitable enough to service its debt. In contrast, high leverage may induce stakeholders to react adversely if the firm is posting losses. Thus, we expect that the mitigating effect of CSR on the costs of high leverage is more pronounced for loss-making firms. To test this idea, we define LOSS, a dummy variable equal to 1 if a firm experiences negative earnings before interest and taxes in a given year. We augment our baseline model with $L O S S$ and its interactions with $C S R, H L E V$, and $C S R \times H L E V$. The results are reported in Table 10. We continue to find that the coefficient on CSR $\times H L E V$ is positive and significant. Importantly, the coefficient on the three-way interaction term $(L O S S \times C S R \times H L E V)$ is also positive and significant, indicating that, consistent with our expectation, the effect of CSR is more pronounced for unprofitable highly leveraged firms.

\subsubsection{CSR decomposition}

To better understand which CSR dimensions reduce the costs of high leverage, we decompose the CSR score into its components. The results are reported in Table 11. We find that the environment and product characteristic dimensions significantly reduce high leverage costs, while the effects of the other CSR dimensions remain statistically insignificant. These findings lend further support to the idea that the effect of CSR on high leverage costs operates through the customer and competitor channels. Better "environment" ratings should help a firm build a positive image among customers, and better "product characteristic" ratings should increase a

firm's customer satisfaction, thus reducing the adverse behavior of customers in the face of high leverage. Moreover, the cost of equity capital is lower for environmentally-friendly firms (El Ghoul et al., 2018) and for firms with higher "product characteristic" ratings (El Ghoul et al., 2011), thus allowing these firms to better withstand competitive attacks.

\subsection{Robustness tests}


In this subsection, we check whether our main results are robust to a battery of sensitivity tests, including using alternative measures of our key variables (leverage, CSR, and sales growth).

Recall that, following Opler and Titman (1994), our primary measure of high leverage is a dummy variable equal to 1 if a firm's leverage ratio in a given year is in the top three deciles of the sample. To address concerns that the three-decile cutoff is arbitrary, we follow Opler and Titman (1994), and assign a value of 1 to top-decile firm-year observations and 0 to bottomdecile observations. Comparisons based on this definition are made between extremely high leveraged firms and extremely low leveraged firms, and thus the results should be more pronounced. As Models 1 and 2 of Table 12 show, the coefficients on HLEV and CSR $\times H L E V$ are two to three times those in the baseline models $(-0.036$ compared to -0.016 , and 0.068 compared to 0.021$)$.

Next, recall that we construct our primary high leverage measure using long-term debt because it is less subject to adjustment, and hence should be more exogenous than short-term debt (Campello, 2006). However, one might argue that the proportions of long- and short-term debt differ across industries. To address this concern, we follow Opler and Titman (1994), and use the total debt ratio, which also incorporates short-term debt. The results in Models 3 and 4 of Table 12 show that, although the significance level declines, CSR continues to reduce the costs of high leverage.

In Models 5 and 6, we lag CSR and HLEV by three years rather than two in order to examine whether the full effects of high leverage take more time to emerge, and, if so, whether the benefits of CSR persist long enough to reduce high leverage costs. This test is inspired by Campello (2006). The results show that the costs of high leverage are decreasing in horizon (-1\% 
at a three-year lag versus $-2.6 \%$ at a two-year lag), but the benefits of CSR are nonetheless similar (2.4\% at a three-year lag versus $2.1 \%$ at a two-year lag).

Next, we turn to alternative proxies for CSR. In Model 7 of Table 12, we use CSR_NET (El Ghoul et al., 2011; Jiao, 2010; Bae et al., 2011), the unadjusted (strengths minus concerns) CSR score. In Model 8, we follow Jo and Harjoto (2012) and divide CSR_NET by the maximum number of strengths and concerns in the same year. Next, given that simple aggregation of the six areas does not account for the relative importance of each area, we follow Goss and Roberts (2011), and use principal component analysis to determine the weight of each dimension. Model 9 reports the results using a measure of CSR equal to the first principal component. Finally, we exclude the corporate governance area from our primary measure of CSR to rule out the possibility that our results are driven by governance effects. But, in Model 10, we report results using a CSR measure based on all seven CSR areas to facilitate comparison with other studies (e.g., Deng et al., 2013). We find that all of the alternative CSR variables generate results in line with CSR reducing high leverage costs.

As an alternative to sales growth, we use market share growth, which reflects the competitive position of the firm in its industry. In Model 11, we find that CSR mitigates the losses of market share growth for highly leveraged firms, reinforcing our main evidence.

In Table 13, we examine whether the results hold after applying alternative industry adjustments and employing different industry classifications. In particular, one might question the consistency of our approach to identifying highly leveraged firms across industries. For example, measuring the leverage in the top three deciles may induce an industry bias. To address this concern, in Model 1 of Table 13, we replace $H L E V$ with the continuous leverage variable (LEVERAGE), and then adjust it by subtracting its industry-year mean. In addition, in Model 2, 
we examine whether our results are robust to using the $10-\mathrm{K}$ text-based fixed industry classification (FIC-100) developed by Hoberg and Phillips $(2010,2016) .{ }^{13}$ We find consistent results that CSR is associated with lower costs of high leverage, suggesting that our main findings are not affected by industry adjustment or alternative industry classifications.

Finally, in additional (untabulated) tests, we examine whether our main finding is affected by the ownership changes of the CSR database. The CSR database was originally maintained by KLD, before being acquired by RiskMetrics Group in 2009 and then sold to MSCI Inc. in 2010. Because several factors were added or dropped in 2010 following these ownership changes, we re-run our analysis for the 1996-2009 period, and find qualitatively similar results.

\section{Conclusion}

Departing from traditional research on agency conflicts between shareholders and bondholders, a growing body of research on the costs of high leverage finds that two playerscustomers and competitors - can exert a significantly negative impact on the product market performance of highly leveraged firms. In this paper, we examine whether corporate social responsibility influences the behavior of these players favorably, and therefore mitigates the costs of high leverage.

Using a large sample of 16,390 firm-year observations representing 2,739 firms, we find that CSR reduces the costs of high leverage as captured by losses in sales growth. CSR appears to provide a risk management benefit. We further find that CSR helps highly leveraged firms keep customers and guard against rival predation, which suggests that the effect of CSR operates through both customer and competitor channels.

\footnotetext{
${ }^{13}$ In unreported tests, we find that our main evidence is not sensitive to using other industry classifications, including the Fama-French 5-, 10-, 12-, 17-, 30-, and 38-industry classifications, and 3- and 4-digit SIC code classifications.
} 
Our study highlights the role of previously unexplored mechanisms through which CSR influences firm value and the strategic importance of CSR as a risk management instrument. Our study also contributes to the debate on whether "doing good" can help a firm "do well." Future research could further our understanding of the effect of CSR on firm value by extending our analysis to a wider set of stakeholders such as employees, suppliers, the community, and the government. 
Appendix A. Six CSR areas in MSCI ESG STATS used in our analysis

\begin{tabular}{|c|c|c|}
\hline & Concerns & Strengths \\
\hline Community & $\begin{array}{l}\text { Investment controversies } \\
\text { Negative economic effects } \\
\text { Indigenous peoples relations } \\
\text { Tax disputes } \\
\text { Other concerns }\end{array}$ & $\begin{array}{l}\text { Charitable giving } \\
\text { Innovative giving } \\
\text { Non-U.S. charitable giving } \\
\text { Support for housing } \\
\text { Support for education } \\
\text { Indigenous peoples relations } \\
\text { Volunteer programs } \\
\text { Other strengths }\end{array}$ \\
\hline Diversity & $\begin{array}{l}\text { Controversies } \\
\text { Non-representation } \\
\text { Other concerns }\end{array}$ & $\begin{array}{l}\text { CEO } \\
\text { Promotion } \\
\text { Board of directors } \\
\text { Work/life benefits } \\
\text { Women and minority contracting } \\
\text { Employment of the disabled } \\
\text { Gay and lesbian policies } \\
\text { Other strengths }\end{array}$ \\
\hline Employee relations & $\begin{array}{l}\text { Union relations } \\
\text { Health and safety concerns } \\
\text { Workforce reductions } \\
\text { Retirement benefits concerns } \\
\text { Other concerns }\end{array}$ & $\begin{array}{l}\text { Union relations } \\
\text { No-layoff policy } \\
\text { Cash profit-sharing } \\
\text { Employee involvement } \\
\text { Retirement benefits strength } \\
\text { Health and safety strength } \\
\text { Other strengths }\end{array}$ \\
\hline Environment & $\begin{array}{l}\text { Hazardous waste } \\
\text { Regulatory problems } \\
\text { Ozone-depleting chemicals } \\
\text { Substantial emissions } \\
\text { Agricultural chemicals } \\
\text { Climate change } \\
\text { Other concerns }\end{array}$ & $\begin{array}{l}\text { Beneficial products and services } \\
\text { Pollution prevention } \\
\text { Recycling } \\
\text { Clean energy } \\
\text { Communications } \\
\text { Property, plant, and equipment } \\
\text { Other strengths }\end{array}$ \\
\hline Human rights & $\begin{array}{l}\text { South Africa } \\
\text { Northern Ireland } \\
\text { Burma concerns } \\
\text { Mexico } \\
\text { Labor rights concerns } \\
\text { Indigenous peoples relations } \\
\text { Other concerns }\end{array}$ & $\begin{array}{l}\text { Positive record in South Africa } \\
\text { Indigenous peoples relations strength } \\
\text { Labor rights strength } \\
\text { Other strengths }\end{array}$ \\
\hline $\begin{array}{l}\text { Product } \\
\text { characteristics }\end{array}$ & Product safety & Quality \\
\hline
\end{tabular}




$\begin{array}{ll}\begin{array}{l}\text { Marketing/contracting } \\ \text { concerns }\end{array} & \mathrm{R} \& \mathrm{D} / \text { innovation } \\ \text { Antitrust } & \begin{array}{l}\text { Benefits to economically } \\ \text { disadvantaged } \\ \text { Other strengths }\end{array} \\ \text { Other concerns } & \text { Oth }\end{array}$

Notes: We consider six CSR areas from MSCI ESG STATS to construct firms' CSR and CSR_NET (as defined in Appendix B): community, diversity, employee relations, environment, human rights, and product characteristics. This table lists the specific strength and concern factors that MSCI assesses in each area. 


\section{Appendix B. Variable definitions and data sources}

\begin{tabular}{|c|c|c|}
\hline Variable & Definition & $\begin{array}{l}\text { Source: } \\
\text { Authors' } \\
\text { calculations } \\
\text { based on }\end{array}$ \\
\hline \multicolumn{3}{|c|}{ Panel A. Corporate social responsibility variables } \\
\hline$C S R \_N E T$ & $\begin{array}{l}\text { Raw CSR score, computed based on six CSR areas in } \\
\text { MSCI ESG STATS: community, diversity, employee } \\
\text { relations, environment, human rights, and product } \\
\text { characteristics. Within each of these areas, various } \\
\text { strengths and concerns are assigned a value of } 0 \text { or } 1 \text {. } \\
\text { For each firm-year, we calculate a score for each CSR } \\
\text { area that is equal to the number of strengths minus the } \\
\text { number of concerns. We then sum the scores of the six } \\
\text { areas. }\end{array}$ & $\begin{array}{l}\text { MSCI ESG } \\
\text { STATS }\end{array}$ \\
\hline$C S R$ & $\begin{array}{l}\text { Adjusted CSR score, computed based on six CSR } \\
\text { areas in MSCI ESG STATS: community, diversity, } \\
\text { employee relations, environment, human rights, and } \\
\text { product characteristics. For each firm-year, we divide } \\
\text { the raw strength (concern) scores of each area by the } \\
\text { maximum number of strengths (concerns) in that area. } \\
\text { We then take the difference between the adjusted } \\
\text { strength and concern scores for that area. }\end{array}$ & As above \\
\hline
\end{tabular}

Panel B. High leverage variables

HLEV High leverage dummy variable equal to 1 if the firm's Compustat long-term debt ratio is in the top three deciles of the overall sample (across industries and over time) in the given year.

Panel C. Outcome variable

SALES_G Sales growth, equal to $\left(S A L E S_{t}-S A L E S_{\mathrm{t}-1}\right) / S A L E S_{t-1}$. As above SALES is total sales.

Panel D. Other variables

SIZE Natural logarithm of total assets. As above

PROFIT Profitability, equal to (operating earnings $+\quad$ As above

INVESTMENT Investment, equal to capital expenditures/total assets. As above

SELLEXP Selling expenses, equal to (advertising + selling, As above general, \& administrative expenses)/total sales. 
E-index

Institutional

Ownership

CEO Pay-

Performance

Sensitivity

Firm R\&D Intensity

Product

Differentiation

Industry Debt Level

Industry

Concentration

(FFC)

Industry

Concentration (HHI)

Customer Sensitivity
Aggregate index of six provisions related to corporate governance: staggered board, limitation on amending bylaws, limitation on amending the charter, supermajority to approve a merger, golden parachute, and poison pill.

Stock ownership by institutional investors.

Delta is the CEO's dollar change in wealth associated with a $1 \%$ change in the firm's stock price.

A firm is classified as a high- (low-) R\&D intensity firm if its $R \& D$-to-sales ratio is greater (smaller) than $0.1 \%$ two years before the base year.

Product differentiation refers to industries that produce services or differentiated (as opposed to standardized) products. Industries with differentiated goods or services have two-digit SIC codes: 25, 27, 30, 32, 34, 35, 36, 37, 38, 39, 41, 42, 44, 45, 47, 48, $49,50,51,52,53,54,55,56,57,59,61,64,65,73$, 75,78 , and 79 , while industries with standardized goods have two-digit SIC codes: 12, 14, 20, 22, 23, 24, 26, 28, 29, 31, and 33 . High- (low-) customer sensitivity refers to industries in which the predominant customer is a consumer (industrial buyer). High-customer sensitivity industries have SIC code ranges: [0,999], [2000,2399], [2500,2599], [2700,2799], [2830,2869], [3000,3219], [3420,3429], 3523, [3600,3669], [3700,3719], 3751, [3850,3879], [3880,3999], 4813, [4830,4899], [5000,5079], [5090,5099], [5130,5159], [5220,5999], [6000,6999], [7000,7299], and [7400,9999]; the remaining industries are defined as low-customer sensitivity industries.

An industry is classified as a high- (low-) debt industry if its average long-term debt ratio is above (below) the median of the overall sample two years before the base year.

An industry is classified as highly (less) concentrated if its $F F C$ is above (below) 0.4 two years before the base year. $F F C$ is the four-firm concentration ratio.

An industry is classified as highly (less) concentrated if its $\mathrm{HHI}$ is above (below) the overall sample median two years before the base year. HHI is the HerfindahlHirschman index.
Institutional

Shareholder

Services

Thomson 13-

F data

Execucomp

Compustat

As above

As above

As above

As above

As above 
Loss dummy equal to 1 if a firm experiences negative As above earnings before interest and taxes.

BLUE Instrument for CSR equal to 1 if a firm's headquarters 270towin.co is in a blue state, and 0 otherwise. Blue states are those $\mathrm{m}$ whose residents vote predominantly for the Democratic party's presidential candidate. 


\section{Acknowledgements}

We thank two anonymous reviewers, as well as Carol Alexander (editor), Allen Berger, Narjess

Boubakri, Marcus V. Braga-Alves, Ruiyuan Chen, Yongtae Kim, Hao Liang, Yrjo Koskinen

(discussant), John Nofsinger (discussant), Youngsuk Yook (discussant), Gordon Roberts, Meir

Statman, He Wang, seminar participants at the University of Rhode Island, and participants at the Asian Finance Association Meeting, Eastern Finance Association Meeting, Financial Management Association Meeting, International Corporate Governance Society Conference, Development Bank of Japan Conference on "CSR, the Economy and Financial Markets," PRI Academic Network Conference, Northern Finance Association Meeting, International Conference on Sustainability \& Responsibility, International Vincentian Business Ethics Conference, Global Finance Conference, and Conference on Asia-Pacific Financial Markets for their helpful comments. El Ghoul acknowledges financial support from the Social Sciences and Humanities Research Council of Canada [grant number 435-2017-1223]. We are solely responsible for any errors. 


\section{References}

Albuquerque, R.A., Koskinen, Y., Zhang, C., 2017. Corporate social responsibility and firm risk: Theory and empirical evidence. Working paper, http://dx.doi.org/10.2139/ssrn.1961971.

Attig, N., El Ghoul, S., Guedhami, O., Suh, J., 2013. Corporate social responsibility and credit ratings. Journal of Business Ethics 117(4), 679-694.

Bae, K.H., Kang, J.K., Wang, J., 2011. Employee treatment and firm leverage: A test of the stakeholder theory of capital structure. Journal of Financial Economics 100(1), 130-153.

Barko, T., Cremers, M., Renneboog, L., 2017. Shareholder engagement on environmental, social, and governance performance. Working paper, http://dx.doi.org/10.2139/ssrn.2977219.

Bebchuk, L., Cohen, A., Ferrell, A., 2009. What matters in corporate governance? Review of Financial Studies 22(2), 783-827.

Blundell, R., Bond, S., 1998. Initial conditions and moment restrictions in dynamic panel data models. Journal of Econometrics 87(1), 115-143.

Bolton, P., Scharfstein, D.S., 1990. A theory of predation based on agency problems in financial contracting. American Economic Review 80(1), 93-106.

Campello, M., 2003. Capital structure and product markets interactions: Evidence from business cycles. Journal of Financial Economics 68(3), 353-378.

Campello, M., 2006. Debt financing: Does it boost or hurt firm performance in product markets? Journal of Financial Economics 82(1), 135-172. 
Campello, M., Fluck, Z., 2006. Product market performance, switching costs, and liquidation values: The real effects of financial leverage. Presented at American Finance Association meetings, 2007, Chicago. http://dx.doi.org/10.2139/ssrn.686435.

Cao, J., Liang, H., Zhan, X., 2018. Peer effects of corporate social responsibility. Management Science, forthcoming.

Cheng, I.H., Hong, H., Shue, K., 2016. Do managers do good with other peoples' money? Working paper, http://dx.doi.org/10.2139/ssrn.1962120.

Chevalier, J.A., 1995. Do LBO supermarkets charge more? An empirical analysis of the effects of LBOs on supermarket pricing. Journal of Finance 50(4), 1095-1112.

Chevalier, J.A., Scharfstein, D., 1996. Capital market imperfections and countercyclical markups: Theory and evidence. American Economic Review 86(4), 703-725.

Corey, E.R., 1991. Industrial Marketing: Cases and Concepts. Prentice-Hall, Englewood Cliffs, NJ.

Cronqvist, H., Heyman, F., Nilsson, M., Svaleryd, H., Vlachos, J., 2009. Do entrenched managers pay their workers more? Journal of Finance 64(1), 309-339.

Deng, X., Kang, J.K., Low, B.S., 2013. Corporate social responsibility and stakeholder value maximization: Evidence from mergers. Journal of Financial Economics 110(1), 87-109.

Di Giuli, A., Kostovetsky, L., 2014. Are red or blue companies more likely to go green? Politics and corporate social responsibility. Journal of Financial Economics 111(1), 158-180.

Edmans, A., 2011. Does the stock market fully value intangibles? Employee satisfaction and equity prices. Journal of Financial Economics 101(3), 621-640. 
El Ghoul, S., Guedhami, O., Kim, H., Park, K., 2018. Corporate environmental responsibility and the cost of capital: International evidence. Journal of Business Ethics 149(2), 335361.

El Ghoul, S., Guedhami, O., Kwok, C.C., Mishra, D.R., 2011. Does corporate social responsibility affect the cost of capital? Journal of Banking and Finance 9(35), 23882406.

Fama, E.F., French, K.R., 1997. Industry costs of equity. Journal of Financial Economics 43(2), 153-193.

Ferrell, A., Liang, H., Renneboog, L., 2016. Socially responsible firms. Journal of Financial Economics 122(3), 585-606.

Flammer, C., 2015. Does corporate social responsibility lead to superior financial performance? A regression discontinuity approach. Management Science 61(11), 2549-2568.

Flammer, C., Kacperczyk, A., 2016. The impact of stakeholder orientation on innovation: Evidence from a natural experiment. Management Science 62(7), 1982-2001.

Freeman, R.E., 1984. Strategic Management: A Stakeholder Approach. Pitman, Boston.

Friedman, M., 1970, September 13. The social responsibility of business is to increase its profits. New York Times Magazine.

Gao, H., Li, K., Ma, Y., 2018. Stakeholder orientation and the cost of debt: Evidence from a natural experiment. Working paper, http://dx.doi.org/10.2139/ssrn.2878415.

Giannetti, M., Burkart, M., Ellingsen, T., 2011. What you sell is what you lend? Explaining trade credit contracts. Review of Financial Studies 24(4), 1261-1298. 
Goss, A., Roberts, G.S., 2011. The impact of corporate social responsibility on the cost of bank loans. Journal of Banking and Finance 35(7), 1794-1810.

Heinkel, R., Kraus, A., Zechner, J., 2001. The effect of green investment on corporate behavior. Journal of Financial and Quantitative Analysis 36(4), 431-449.

Hoberg, G., Phillips, G. 2010. Product market synergies and competition in mergers and acquisitions: A text-based analysis. Review of Financial Studies, 23(10), 3773-3811.

Hoberg, G., Phillips, G. 2016. Text-based network industries and endogenous product differentiation. Journal of Political Economy 124(5),1423-1465.

Hong, H., Kacperczyk, M. 2009. The price of sin: the effects of social norms on markets. Journal of Financial Economics 93(1), 15-36.

Hong, H., Liskovich, I., 2015. Crime, punishment and the halo effect of corporate social responsibility. NBER Working Paper No. 21215, http://www.nber.org/papers/w21215.

Jensen, M.C., 1986. Agency costs of free cash flow, corporate finance, and takeovers. American Economic Review 76(2), 323-329.

Jiao, Y., 2010. Stakeholder welfare and firm value. Journal of Banking and Finance 10(34), 2549-2561.

Jo, H., Harjoto, M.A., 2012. The causal effect of corporate governance on corporate social responsibility. Journal of Business Ethics 106(1), 53-72.

Jung, J.H., Kang, J.K., Lim, S.S., Yoo, C.Y., 2016. Perceived firm trustworthiness and market underreaction to earnings news. Working paper, http://dx.doi.org/10.2139/ssrn.2544247. 
Kini, O., Shenoy, J., Subramaniam, V., 2017. Impact of financial leverage on the incidence and severity of product failures: Evidence from product recalls. Review of Financial Studies 30(5), 1790-1829.

Kitzmueller, M., Shimshack, J., 2012. Economic perspectives on corporate social responsibility. Journal of Economic Literature 50(1), 51-84.

Krüger, P., 2015. Corporate goodness and shareholder wealth. Journal of Financial Economics 115(2), 304-329.

Lang, L.H., Stulz, R. 1992. Contagion and competitive intra-industry effects of bankruptcy announcements: An empirical analysis. Journal of Financial Economics 32(1), 45-60.

Lev, B., Petrovits, C., Radhakrishnan, S., 2010. Is doing good good for you? How corporate charitable contributions enhance revenue growth. Strategic Management Journal 31(2), $182-200$.

Lins, K.V., Servaes, H., Tamayo, A., 2017. Social capital, trust, and firm performance: The value of corporate social responsibility during the financial crisis. Journal of Finance 72(4), 1785-1824.

Lins, K.V., Volpin, P., Wagner, H., 2013. Does family control matter? International evidence from the 2008-2009 financial crisis. Review of Financial Studies 26(10), 2583-2619.

Maksimovic, V., Titman, S., 1991. Financial policy and reputation for product quality. Review of Financial Studies 4(1), 175-200.

Masulis, R.W., Reza, S.W., 2015. Agency problems of corporate philanthropy. Review of Financial Studies 28(2), 592-636. 
Matsa, D.A., 2011. Running on empty? Financial leverage and product quality in the supermarket industry. American Economic Journal: Microeconomics 3(1), 137-173.

Merton, R.C., 1987. A simple model of capital market equilibrium with incomplete information. Journal of Finance 42(3), 483-510.

Opler, T.C., Titman, S., 1994. Financial distress and corporate performance. Journal of Finance 49(3), 1015-1040.

Pagano, M., Volpin, P.F., 2005. Managers, workers, and corporate control. Journal of Finance $60(2), 841-868$.

Rauch, J.E., 1999. Networks versus markets in international trade. Journal of International Economics 48(1), 7-35.

Servaes, H., Tamayo, A., 2013. The impact of corporate social responsibility on firm value: The role of customer awareness. Management Science 59(5), 1045-1061.

Telser, L.G., 1966. Cutthroat competition and the long purse. Journal of Law and Economics 9, 259-277.

Titman, S., 1984. The effect of capital structure on a firm's liquidation decision. Journal of Financial Economics 13(1), 137-151.

Titman, S., Wessels, R., 1988. The determinants of capital structure choice. Journal of Finance 43(1), 1-19.

Waddock, S.A., Graves, S.B., 1997. The corporate social performance-financial performance link. Strategic Management Journal 18(4), 303-319. 
Table 1. Sample distribution by industry and year

\begin{tabular}{|c|c|c|c|}
\hline \# & Industry & $\mathrm{N}$ & $\%$ \\
\hline 1 & Agriculture & 51 & 0.31 \\
\hline 2 & Food products & 417 & 2.54 \\
\hline 3 & Candy \& soda & 45 & 0.27 \\
\hline 4 & Beer \& liquor & 101 & 0.62 \\
\hline 5 & Tobacco products & 29 & 0.18 \\
\hline 6 & Recreation & 102 & 0.62 \\
\hline 7 & Entertainment & 228 & 1.39 \\
\hline 8 & Printing \& publishing & 204 & 1.24 \\
\hline 9 & Consumer goods & 401 & 2.45 \\
\hline 10 & Apparel & 344 & 2.10 \\
\hline 11 & Healthcare & 200 & 1.22 \\
\hline 12 & Medical equipment & 579 & 3.53 \\
\hline 13 & Pharmaceutical products & 708 & 4.32 \\
\hline 14 & Chemicals & 578 & 3.53 \\
\hline 15 & Rubber \& plastic products & 111 & 0.68 \\
\hline 16 & Textiles & 26 & 0.16 \\
\hline 17 & Construction materials & 390 & 2.38 \\
\hline 18 & Construction & 254 & 1.55 \\
\hline 19 & Steelworks & 280 & 1.71 \\
\hline 20 & Fabricated products & 5 & 0.03 \\
\hline 21 & Machinery & 827 & 5.05 \\
\hline 22 & Electrical equipment & 288 & 1.76 \\
\hline 23 & Automobiles \& trucks & 365 & 2.23 \\
\hline 24 & Aircraft & 155 & 0.95 \\
\hline 25 & Shipbuilding \& industrial metal mining & 40 & 0.24 \\
\hline 26 & Defense & 50 & 0.31 \\
\hline 27 & Precious metals & 3 & 0.02 \\
\hline 28 & Non-metallic \& industrial metal mining & 72 & 0.44 \\
\hline 29 & Coal & 59 & 0.36 \\
\hline 30 & Petroleum \& natural gas & 828 & 5.05 \\
\hline 32 & Communications & 599 & 3.65 \\
\hline 33 & Personal services & 248 & 1.51 \\
\hline 34 & Business services & 2,017 & 12.31 \\
\hline 35 & Computers & 757 & 4.62 \\
\hline 36 & Electronic equipment & 1,303 & 7.95 \\
\hline 37 & Measuring \& control equipment & 442 & 2.70 \\
\hline 38 & Business supplies & 370 & 2.26 \\
\hline 39 & Shipping containers & 75 & 0.46 \\
\hline
\end{tabular}




\begin{tabular}{llcc}
40 & Transportation & 348 & 2.12 \\
41 & Wholesale & 608 & 3.71 \\
42 & Retail & 1,463 & 8.93 \\
43 & Restaurants, hotels \& motels & 359 & 2.19 \\
46 & Real estate & 61 & 0.37 \\
& Total & 16,390 & 100.00 \\
\hline
\end{tabular}

Panel B. Sample distribution by year

\begin{tabular}{lcc}
\hline Year & $\mathrm{N}$ & $\%$ \\
\hline 1996 & 340 & 2.07 \\
1997 & 340 & 2.07 \\
1998 & 331 & 2.02 \\
1999 & 327 & 2.00 \\
2000 & 322 & 1.96 \\
2001 & 333 & 2.03 \\
2002 & 345 & 2.10 \\
2003 & 589 & 3.59 \\
2004 & 622 & 3.79 \\
2005 & 1,600 & 9.76 \\
2006 & 1,619 & 9.88 \\
2007 & 1,565 & 9.55 \\
2008 & 1,575 & 9.61 \\
2009 & 1,612 & 9.84 \\
2010 & 1,678 & 10.24 \\
2011 & 1,656 & 10.10 \\
2012 & 1,536 & 9.37 \\
Total & 16,390 & 100.00 \\
\hline Nos & & \\
\hline
\end{tabular}

Notes: This table presents the Fama-French (1997) 48-industry and fiscal year distributions for our sample of 16,390 firm-year observations representing 2,739 unique firms. 
Table 2. Descriptive statistics

\begin{tabular}{|c|c|c|c|c|c|c|c|}
\hline & Mean & SD & Minimum & Q1 & Median & Q3 & Maximum \\
\hline$S A L E S \_G_{t}$ & 0.08 & 0.22 & -0.98 & -0.01 & 0.07 & 0.16 & 1.95 \\
\hline$C S R_{t-2}$ & -0.14 & 0.48 & -3.00 & -0.40 & -0.17 & 0.09 & 3.83 \\
\hline$H L E V_{t-2}$ & 0.29 & 0.45 & 0.00 & 0.00 & 0.00 & 1.00 & 1.00 \\
\hline$S I Z E_{t}$ & 7.30 & 1.58 & 1.07 & 6.15 & 7.22 & 8.33 & 12.72 \\
\hline PROFIT $_{t-1}$ & 0.08 & 0.14 & -2.66 & 0.05 & 0.09 & 0.13 & 0.38 \\
\hline PROFIT $_{t-2}$ & 0.08 & 0.14 & -3.57 & 0.05 & 0.09 & 0.14 & 0.38 \\
\hline$I_{N V E S T M E N T} T_{t-1}$ & 0.05 & 0.06 & 0.00 & 0.02 & 0.04 & 0.07 & 0.40 \\
\hline INVESTMENT $_{t-2}$ & 0.06 & 0.06 & 0.00 & 0.02 & 0.04 & 0.07 & 0.40 \\
\hline$S E L L E X P_{t-1}$ & 0.31 & 0.45 & 0.02 & 0.13 & 0.24 & 0.38 & 10.72 \\
\hline$S E L L E X P_{t-2}$ & 0.31 & 0.44 & 0.02 & 0.13 & 0.24 & 0.38 & 10.72 \\
\hline
\end{tabular}

Notes: This table reports the descriptive statistics for the key variables (before industry-year adjustments) used in Equations (1) and (2). The sample comprises 16,390 firm-year observations representing 2,739 unique firms. 
Table 3. CSR and the costs of high leverage

\begin{tabular}{|c|c|c|c|c|}
\hline & OLS & OLS & $\begin{array}{l}\text { Firm Fixed } \\
\text { Effects }\end{array}$ & $\begin{array}{c}C S R \_S T R_{t-2} \& \\
C S R \_C O N_{t-2}\end{array}$ \\
\hline & (1) & (2) & (3) & (4) \\
\hline$C S R_{t-2} \times H L E V_{t-2}$ & & $\begin{array}{l}0.025^{* * *} \\
(3.28)\end{array}$ & $\begin{array}{l}0.021 * * * \\
(2.57)\end{array}$ & \\
\hline$C S R \_S T R_{t-2} \times H L E V_{t-2}$ & & & & $\begin{array}{l}0.024 * * \\
(2.16)\end{array}$ \\
\hline$C S R \_C O N_{t-2} \times H L E V_{t-2}$ & & & & $\begin{array}{l}-0.018^{*} \\
(-1.86)\end{array}$ \\
\hline$H L E V_{t-2}$ & $\begin{array}{l}-0.016 \text { *** } \\
(-3.86)\end{array}$ & $\begin{array}{l}-0.015 * * * \\
(-3.85)\end{array}$ & $\begin{array}{l}-0.026^{* * *} \\
(-4.42)\end{array}$ & $\begin{array}{l}-0.026 * * * \\
(-3.28)\end{array}$ \\
\hline$C S R_{t-2}$ & & $\begin{array}{l}-0.010 * * \\
(-2.11)\end{array}$ & $\begin{array}{l}-0.014^{* *} \\
(-2.48)\end{array}$ & \\
\hline$C S R \_S T R_{t-2}$ & & & & $\begin{array}{l}-0.015 \\
(-1.55)\end{array}$ \\
\hline$C S R \_C O N_{t-2}$ & & & & $\begin{array}{r}0.014 \\
(1.09)\end{array}$ \\
\hline$S I Z E_{t}$ & $\begin{array}{l}-0.000 \\
(-0.02)\end{array}$ & $\begin{array}{c}0.000 \\
(0.19)\end{array}$ & $\begin{array}{l}0.051^{* * *} \\
(7.85)\end{array}$ & $\begin{array}{l}0.051^{* * * *} \\
(6.82)\end{array}$ \\
\hline PROFIT $_{t-1}$ & $\begin{array}{l}0.064^{* * * *} \\
(3.11)\end{array}$ & $\begin{array}{l}0.064^{* * * *} \\
(3.13)\end{array}$ & $\begin{array}{r}-0.022 \\
(-0.90)\end{array}$ & $\begin{array}{r}-0.022 \\
(-0.56)\end{array}$ \\
\hline PROFIT $_{t-2}$ & $\begin{array}{l}-0.006 \\
(-0.29)\end{array}$ & $\begin{array}{l}-0.006 \\
(-0.27)\end{array}$ & $\begin{array}{l}-0.020 \\
(-0.82)\end{array}$ & $\begin{array}{l}-0.021 \\
(-0.54)\end{array}$ \\
\hline INVESTMENT $T_{t-1}$ & $\begin{array}{l}0.323^{* * *} \\
(3.75)\end{array}$ & $\begin{array}{l}0.324 * * * \\
(3.78)\end{array}$ & $\begin{array}{l}-0.023 \\
(-0.26)\end{array}$ & $\begin{array}{l}-0.021 \\
(-0.17)\end{array}$ \\
\hline$I_{N V E S T M E N T}$ & $\begin{array}{r}0.111 \\
(1.39)\end{array}$ & $\begin{array}{r}0.112 \\
(1.40)\end{array}$ & $\begin{array}{l}-0.135 \\
(-1.37)\end{array}$ & $\begin{array}{l}-0.135 \\
(-1.38)\end{array}$ \\
\hline$S E L L E X P_{t-1}$ & $\begin{array}{r}0.000 \\
(0.00)\end{array}$ & $\begin{array}{c}0.000 \\
(0.01)\end{array}$ & $\begin{array}{l}0.040^{* * *} \\
(2.62)\end{array}$ & $\begin{array}{r}0.040 \\
(0.85)\end{array}$ \\
\hline$S E L L E X P_{t-2}$ & $\begin{array}{c}0.018 \\
(1.17)\end{array}$ & $\begin{array}{r}0.019 \\
(1.18)\end{array}$ & $\begin{array}{l}0.054 * * \\
(2.52)\end{array}$ & $\begin{array}{l}0.053^{* * *} \\
(4.98)\end{array}$ \\
\hline CONSTANT & $\begin{array}{l}-0.009 * * \\
(-2.37)\end{array}$ & $\begin{array}{l}-0.009 * * \\
(-2.44)\end{array}$ & $\begin{array}{l}-0.061^{* * *} \\
(-4.87)\end{array}$ & $\begin{array}{l}-0.061^{* * *} \\
(-3.06)\end{array}$ \\
\hline$N$ & 16,390 & 16,390 & 16,390 & 16,315 \\
\hline$R$-squared & 0.012 & 0.013 & 0.019 & 0.019 \\
\hline
\end{tabular}

Notes: This table reports the results for the costs of high leverage (Model 1), the effect of CSR on the costs of high leverage using OLS (Model 2) and firm fixed-effect model (Model 3), and the effect of CSR strengths and concerns on the costs of high leverage (Model 4). The dependent variable is industry-adjusted sales growth (SALES_G). The main variables of interest are industry-adjusted CSR (CSR) and a dummy variable equal to 1 if the firm's long-term debt-to-assets ratio is in the top three deciles of the overall sample in the given year (HLEV). Variable definitions are provided in Appendix B. All the control variables are adjusted to their industry-year means, and are winsorized at the $1 \%$ and $99 \%$ levels to mitigate the influence of outliers. To ensure that the industry-year mean is not biased toward outliers, we require that each industry-year contain at least four firms. The sample period is 1996-2012. The reported $t$-statistics are based on robust standard errors adjusted for clustering at the firm level. ***, **, and * denote statistical significance at the $1 \%, 5 \%$, and $10 \%$ levels, respectively. 
Table 4. CSR and corporate governance

\begin{tabular}{|c|c|c|c|}
\hline \multirow[t]{2}{*}{ Dependent variable: } & E-Index & Institutional Ownership & CEO Pay-performance Sensitivity \\
\hline & (1) & (2) & (3) \\
\hline$C S R_{t-2}$ & $\begin{array}{l}0.016 \\
(0.53)\end{array}$ & $\begin{array}{c}0.002 \\
(0.46)\end{array}$ & $\begin{array}{c}25.780 \\
(1.29)\end{array}$ \\
\hline$H L E V_{t-2}$ & $\begin{array}{c}-0.069^{* *} \\
(-2.26)\end{array}$ & $\begin{array}{c}0.006 \\
(1.56)\end{array}$ & $\begin{array}{c}-4.005 \\
(-0.18)\end{array}$ \\
\hline$S I Z E_{t}$ & $\begin{array}{c}0.315 * * * \\
(8.74)\end{array}$ & $\begin{array}{l}0.013 \text { *** } \\
(2.77)\end{array}$ & $\begin{array}{c}20.983 \\
(0.78)\end{array}$ \\
\hline PROFIT $_{t-1}$ & $\begin{array}{c}0.224 * * * \\
(2.80)\end{array}$ & $\begin{array}{l}0.087 * * * \\
(7.89)\end{array}$ & $\begin{array}{c}-63.192 \\
(-1.15)\end{array}$ \\
\hline PROFIT $_{t-2}$ & $\begin{array}{c}0.140^{*} \\
(1.86)\end{array}$ & $\begin{array}{l}0.040 * * * \\
(3.67)\end{array}$ & $\begin{array}{l}-7.365 \\
(-0.10)\end{array}$ \\
\hline INVESTMENT $_{t-1}$ & $\begin{array}{c}-0.477 * \\
(-1.74)\end{array}$ & $\begin{array}{r}0.037 \\
(0.97)\end{array}$ & $\begin{array}{c}-472.523 \\
(-1.14)\end{array}$ \\
\hline INVESTMENT $_{t-2}$ & $\begin{array}{l}-0.274 \\
(-1.03)\end{array}$ & $\begin{array}{r}-0.057 \\
(-1.43)\end{array}$ & $\begin{array}{c}-15.291 \\
(-0.09)\end{array}$ \\
\hline$S E L L E X P_{t-1}$ & $\begin{array}{l}-0.056 \\
(-1.36)\end{array}$ & $\begin{array}{l}0.019^{* * *} \\
(3.39)\end{array}$ & $\begin{array}{c}-13.562 \\
(-0.93)\end{array}$ \\
\hline$S E L L E X P_{t-2}$ & $\begin{array}{l}0.019 \\
(0.51)\end{array}$ & $\begin{array}{l}0.012 * * \\
(1.96)\end{array}$ & $\begin{array}{l}1.895 \\
(0.15)\end{array}$ \\
\hline CONSTANT & $\begin{array}{c}-1.048^{* * *} \\
(-12.49)\end{array}$ & $\begin{array}{l}-0.039 * * * \\
(-4.00)\end{array}$ & $\begin{array}{c}-41.859 \\
(-0.58)\end{array}$ \\
\hline$N$ & 16,298 & 10,779 & 4,313 \\
\hline$R$-squared & 0.066 & 0.020 & 0.000 \\
\hline
\end{tabular}

Notes: This table reports the results for the effect of CSR on corporate governance using a firm fixed-effect model. The dependent corporate governance variables are E-Index (Model 1), Institutional Ownership (Model 2), and CEO Pay-Performance Sensitivity (Model 3). The dependent variables are industry-adjusted. The main variables of interest are industry-adjusted CSR (CSR), and a dummy variable equal to 1 if the firm's long-term debt-to-assets ratio is in the top three deciles of the overall sample in the given year (HLEV). Variable definitions are provided in Appendix B. All the control variables are adjusted to their industry-year means, and are winsorized at the $1 \%$ and $99 \%$ levels to mitigate the influence of outliers. To ensure that the industry-year mean is not biased toward outliers, we require that each industry-year contain at least four firms. The reported $t$-statistics are based on robust standard errors adjusted for clustering at the firm level (Models 1 and 2) and manager level (Model 3). ***,**, and * denote statistical significance at the $1 \%, 5 \%$, and $10 \%$ levels, respectively. 
Table 5. CSR and the costs of high leverage: Additional controls for corporate governance

\begin{tabular}{|c|c|c|c|}
\hline & (1) & $(2)$ & (3) \\
\hline \multirow[t]{2}{*}{$C S R_{t-2} \times H L E V_{t-2}$} & $0.022 * * *$ & $0.030 * * *$ & $0.021 * *$ \\
\hline & $(2.62)$ & $(3.07)$ & $(2.03)$ \\
\hline \multirow[t]{2}{*}{$H L E V_{t-2}$} & $-0.025 * * *$ & $-0.030 * * *$ & $-0.028 * * *$ \\
\hline & $(-4.22)$ & $(-4.28)$ & $(-4.67)$ \\
\hline \multirow[t]{2}{*}{$C S R_{t-2}$} & $-0.015^{* *}$ & $-0.019 * * *$ & $-0.014 * *$ \\
\hline & $(-2.50)$ & $(-2.70)$ & $(-2.19)$ \\
\hline \multirow[t]{2}{*}{$E-I n d e x_{t-2} \times H L E V_{t-2}$} & -0.002 & & \\
\hline & $(-0.55)$ & & \\
\hline \multirow[t]{2}{*}{ E-Index $t_{t-2}$} & 0.001 & & \\
\hline & $(0.20)$ & & \\
\hline \multirow[t]{2}{*}{ Institutional Ownership t-2 $\times H L E V_{t-2}$} & & 0.006 & \\
\hline & & $(0.18)$ & \\
\hline \multirow[t]{2}{*}{ Institutional Ownership $p_{t-2}$} & & $0.093 * * *$ & \\
\hline & & $(2.81)$ & \\
\hline \multirow[t]{2}{*}{ CEO Pay-Performance Sensitivityt-2 $\times H L E V_{t-2}$} & & & 0.000 \\
\hline & & & $(0.81)$ \\
\hline \multirow[t]{2}{*}{ CEO Pay-Performance Sensitivity ${ }_{t-2}$} & & & 0.000 \\
\hline & & & $(1.04)$ \\
\hline \multirow[t]{2}{*}{$S I Z E_{t}$} & $0.051 * * *$ & $0.041 * * *$ & $0.010 * * *$ \\
\hline & $(7.78)$ & $(5.28)$ & $(5.71)$ \\
\hline \multirow[t]{2}{*}{ PROFIT $_{t-1}$} & -0.022 & -0.013 & $-0.125^{* * *}$ \\
\hline & $(-0.89)$ & $(-0.41)$ & $(-4.11)$ \\
\hline \multirow[t]{2}{*}{ PROFIT $_{t-2}$} & -0.019 & $-0.053 *$ & $0.205^{* * *}$ \\
\hline & $(-0.78)$ & $(-1.71)$ & $(6.40)$ \\
\hline \multirow[t]{2}{*}{$I_{N V E S T M E N T} T_{t-1}$} & -0.024 & -0.069 & -0.083 \\
\hline & $(-0.27)$ & $(-0.58)$ & $(-0.70)$ \\
\hline \multirow[t]{2}{*}{ INVESTMENT $_{t-2}$} & -0.136 & $-0.261^{* *}$ & 0.108 \\
\hline & $(-1.38)$ & $(-2.34)$ & $(0.98)$ \\
\hline \multirow[t]{2}{*}{$S E L L E X P_{t-1}$} & $0.039 * * *$ & -0.011 & $-0.083 * * *$ \\
\hline & $(2.59)$ & $(-0.39)$ & $(-8.10)$ \\
\hline \multirow[t]{2}{*}{$S E L L E X P_{t-2}$} & $0.054 * *$ & $0.060 * *$ & $0.142 * * *$ \\
\hline & $(2.53)$ & $(2.47)$ & $(11.87)$ \\
\hline \multirow[t]{2}{*}{ CONSTANT } & $-0.062 * * *$ & $-0.048 * * *$ & $-0.041 * * *$ \\
\hline & $(-4.87)$ & $(-2.84)$ & $(-7.47)$ \\
\hline$N$ & 16,298 & 10,779 & 4,313 \\
\hline$R$-squared & 0.019 & 0.016 & 0.053 \\
\hline
\end{tabular}

Notes: This table reports the effect of CSR on the costs of high leverage using a firm fixed-effect model that controls for E-Index (Model 1) and Institutional Ownership (Model 2), and a manager fixed-effect model that controls for CEO Pay-Performance Sensitivity (Model 3). The dependent variable is industry-adjusted sales growth (SALES_G). The main variables of interest are industry-adjusted CSR (CSR), and a dummy variable equal to 1 if the firm's long-term debt-to-assets ratio is in the top three deciles of the overall sample in the given year (HLEV). Variable definitions are provided in Appendix B. All the control variables are adjusted to their industry-year means, and are winsorized at the $1 \%$ and $99 \%$ levels to mitigate the influence of outliers. To ensure that the industry-year mean is not biased toward outliers, we require that each industry-year contain at least four firms. The reported $t$-statistics are based on robust standard errors adjusted for clustering at the firm level (Models 1 and 2) and manager level (Model 3). ***, ${ }^{* *}$, and ${ }^{*}$ 
denote statistical significance at the $1 \%, 5 \%$, and $10 \%$ levels, respectively. 
Table 6. Endogeneity tests: 2SLS and system GMM

\begin{tabular}{|c|c|c|c|c|c|c|c|c|}
\hline \multirow{3}{*}{ Endogenous variables: } & \multicolumn{5}{|c|}{ 2SLS } & \multicolumn{3}{|c|}{ System GMM } \\
\hline & \multicolumn{2}{|c|}{ First Stage } & \multicolumn{3}{|c|}{ Second Stage } & \multirow[b]{2}{*}{$\begin{array}{l}H L E V_{t-2} \\
\quad(6)\end{array}$} & \multirow[b]{2}{*}{$\begin{array}{c}C S R_{t-2} \\
(7)\end{array}$} & \multirow[b]{2}{*}{$\begin{array}{c}C S R_{t-2} \& H L E V_{t-2} \\
\text { (8) }\end{array}$} \\
\hline & $\begin{array}{c}H L E V_{t-2} \\
(1)\end{array}$ & $\begin{array}{c}C S R_{t-2} \\
(2)\end{array}$ & $\begin{array}{c}H L E V_{t-2} \\
(3)\end{array}$ & $\begin{array}{c}C S R_{t-2} \\
(4)\end{array}$ & $\begin{array}{c}C S R_{t-2} \& H L E V_{t-2} \\
(5)\end{array}$ & & & \\
\hline$C S R_{t-2} \times H L E V_{t-2}$ & & & & $\begin{array}{l}0.021 * * \\
(2.05)\end{array}$ & $\begin{array}{l}0.037 * * * \\
(2.58)\end{array}$ & & $\begin{array}{l}0.016^{* *} \\
(2.34)\end{array}$ & $\begin{array}{l}0.021 * * * \\
(3.28)\end{array}$ \\
\hline$H L E V_{t-2}$ & & $\begin{array}{l}-0.007 \\
(-1.19)\end{array}$ & $\begin{array}{l}-0.016^{* * *} \\
(-2.84)\end{array}$ & $\begin{array}{l}-0.015^{* * *} \\
(-3.46)\end{array}$ & $\begin{array}{l}-0.014^{* *} \\
(-2.37)\end{array}$ & $\begin{array}{l}-0.014 * * * \\
(-3.14)\end{array}$ & $\begin{array}{c}-0.017 * * * \\
(-3.23)\end{array}$ & $\begin{array}{l}-0.015^{* * * *} \\
(-3.64)\end{array}$ \\
\hline $\operatorname{CSR}_{t-2}$ & & & & $\begin{array}{l}-0.008 \\
(-1.25)\end{array}$ & $\begin{array}{l}-0.013^{*} \\
(-1.96)\end{array}$ & & $\begin{array}{l}-0.011 * * \\
(-2.52)\end{array}$ & $\begin{array}{l}-0.013^{* * * *} \\
(-3.26)\end{array}$ \\
\hline$S_{Z I Z E_{t}}$ & $\begin{array}{l}0.010 * * * \\
(6.36)\end{array}$ & $\begin{array}{l}0.018 * * * \\
(9.90)\end{array}$ & $\begin{array}{l}-0.000 \\
(-0.02)\end{array}$ & $\begin{array}{c}0.001 \\
(0.45)\end{array}$ & $\begin{array}{r}0.001 \\
(0.48)\end{array}$ & $\begin{array}{l}0.004 * * * \\
(2.74)\end{array}$ & $\begin{array}{c}0.005^{* * * *} \\
(3.75)\end{array}$ & $\begin{array}{l}0.004 * * * \\
(3.47)\end{array}$ \\
\hline PROFIT $_{t-1}$ & $\begin{array}{l}-0.048^{* *} \\
(-2.18)\end{array}$ & $\begin{array}{c}0.012 \\
(0.71)\end{array}$ & $\begin{array}{l}0.076^{* * * *} \\
(3.65)\end{array}$ & $\begin{array}{l}0.077 * * * \\
(3.57)\end{array}$ & $\begin{array}{l}0.078 * * * \\
(3.58)\end{array}$ & $\begin{array}{l}-0.033 \\
(-0.56)\end{array}$ & $\begin{array}{c}-0.018 \\
(-0.31)\end{array}$ & $\begin{array}{c}-0.018 \\
(-0.43)\end{array}$ \\
\hline PROFIT $_{t-2}$ & $\begin{array}{l}-0.214 \text { *** } \\
(-8.29)\end{array}$ & $\begin{array}{l}0.056^{* * *} \\
(3.02)\end{array}$ & $\begin{array}{l}-0.025 \\
(-1.02)\end{array}$ & $\begin{array}{l}-0.013 \\
(-0.50)\end{array}$ & $\begin{array}{l}-0.027 \\
(-1.02)\end{array}$ & $\begin{array}{r}0.005 \\
(0.14)\end{array}$ & $\begin{array}{c}0.004 \\
(0.13)\end{array}$ & $\begin{array}{l}-0.006 \\
(-0.20)\end{array}$ \\
\hline$I_{N V E S T M E N T} T_{t-1}$ & $\begin{array}{l}-0.269 * * * \\
(-3.13)\end{array}$ & $\begin{array}{l}-0.007 \\
(-0.11)\end{array}$ & $\begin{array}{l}0.238 * * * \\
(2.76)\end{array}$ & $\begin{array}{l}0.268 * * * \\
(2.86)\end{array}$ & $\begin{array}{l}0.216^{* *} \\
(2.45)\end{array}$ & $\begin{array}{l}-0.026 \\
(-0.17)\end{array}$ & $\begin{array}{c}0.009 \\
(0.06)\end{array}$ & $\begin{array}{l}-0.028 \\
(-0.24)\end{array}$ \\
\hline$I_{N V E S T M E N T_{t-2}}$ & $\begin{array}{l}0.393 * * * \\
(4.58)\end{array}$ & $\begin{array}{l}0.149 * * \\
(2.30)\end{array}$ & $\begin{array}{l}0.151^{*} \\
(1.80)\end{array}$ & $\begin{array}{l}0.133 \\
(1.53)\end{array}$ & $\begin{array}{l}0.178 * * \\
(2.07)\end{array}$ & $\begin{array}{l}0.199 * * \\
(2.06)\end{array}$ & $\begin{array}{l}0.171^{*} \\
(1.78)\end{array}$ & $\begin{array}{l}0.216^{* *} \\
(2.26)\end{array}$ \\
\hline$S E L L E X P_{t-1}$ & $\begin{array}{l}-0.011 \\
(-1.07)\end{array}$ & $\begin{array}{l}-0.007 \\
(-0.51)\end{array}$ & $\begin{array}{l}-0.013 \\
(-0.97)\end{array}$ & $\begin{array}{l}-0.037 * * \\
(-2.47)\end{array}$ & $\begin{array}{l}-0.034 * * \\
(-2.20)\end{array}$ & $\begin{array}{r}-0.009 \\
(-0.40)\end{array}$ & $\begin{array}{l}-0.008 \\
(-0.32)\end{array}$ & $\begin{array}{l}-0.010 \\
(-0.47)\end{array}$ \\
\hline$S E L L E X P_{t-2}$ & $\begin{array}{l}-0.037 * * * \\
(-3.32)\end{array}$ & $\begin{array}{l}0.026^{* * *} \\
(1.99)\end{array}$ & $\begin{array}{l}0.029^{*} \\
(1.75)\end{array}$ & $\begin{array}{l}0.062 * * * \\
(3.69)\end{array}$ & $\begin{array}{l}0.052^{* * * *} \\
(2.81)\end{array}$ & $\begin{array}{c}0.024 \\
(0.80)\end{array}$ & $\begin{array}{c}0.029 \\
(1.02)\end{array}$ & $\begin{array}{c}0.023 \\
(0.93)\end{array}$ \\
\hline$B L U E_{t-2}$ & & $\begin{array}{l}0.900 * * * \\
(109.90)\end{array}$ & & & & & & \\
\hline$C S R_{t-3}$ & & $\begin{array}{l}0.015^{* * * *} \\
(3.11)\end{array}$ & & & & & & \\
\hline$H L E V_{t-3}$ & $\begin{array}{l}0.618 * * * \\
(55.07)\end{array}$ & & & & & & & \\
\hline$H L E V_{t-4}$ & $0.143 * * *$ & & & & & & & \\
\hline
\end{tabular}


(12.80)

\begin{tabular}{|c|c|c|c|c|c|c|c|c|}
\hline$S A L E S G_{t-1}$ & & & & & & $\begin{array}{c}0.317 \\
(1.44)\end{array}$ & $\begin{array}{c}0.285 \\
(1.31)\end{array}$ & $\begin{array}{l}0.280^{* *} \\
(2.04)\end{array}$ \\
\hline CONSTANT & $\begin{array}{l}0.075^{* * *} \\
(17.56)\end{array}$ & $\begin{array}{l}-0.041 \text { *** } \\
(-7.62)\end{array}$ & $\begin{array}{l}-0.010 * * \\
(-2.57)\end{array}$ & $\begin{array}{l}-0.011^{* *} \\
(-2.57)\end{array}$ & $\begin{array}{l}-0.011^{* * *} \\
(-2.59)\end{array}$ & $\begin{array}{c}-0.003 \\
(-0.56)\end{array}$ & $\begin{array}{c}-0.004 \\
(-0.72)\end{array}$ & $\begin{array}{l}-0.005 \\
(-1.16)\end{array}$ \\
\hline$N$ & 15,613 & 13,386 & 15,613 & 13,386 & 13,107 & 13,021 & 13,295 & 13,020 \\
\hline$R$-squared & 0.564 & 0.622 & 0.011 & 0.015 & 0.013 & & & \\
\hline First-stage $F$-statistic $\left(C S R_{t-2}\right)$ & - & $6,091.95$ & - & $6,091.95$ & $6,871.28$ & & & \\
\hline First-stage $F$-statistic $\left(H L E V_{t-2}\right)$ & $9,137.29$ & - & $9,137.29$ & - & $5,179.01$ & & & \\
\hline$F$-statistic of exogeneity & & & 0.20 & 0.48 & 0.42 & & & \\
\hline overid test $J$-statistic & & & 0.40 & 0.96 & 1.68 & & & \\
\hline overid test $J$-statistic $p$-value & & & 0.53 & 0.33 & 0.43 & & & \\
\hline Sargan test of overid. Chi2 & & & & & & 6.24 & 16.02 & 23.99 \\
\hline Sargan test of overid. $p$-value & & & & & & 0.99 & 1.00 & 1.00 \\
\hline Hansen test of overid. Chi2 & & & & & & 8.07 & 27.70 & 39.97 \\
\hline Hansen test of overid. $p$-value & & & & & & 0.97 & 0.77 & 0.936 \\
\hline $\begin{array}{l}\text { Notes: This table reports } 2 \text { SLS anc } \\
\text { interest are industry-adjusted CSR } \\
\text { sample in the given year (HLEV). } \\
\text { winsorized at the } 1 \% \text { and } 99 \% \text { lev } \\
\text { headquartered in a Democratic stat } \\
\text { its lagged values over the past two } \\
\text { Model } 3 \text { reports the second-stage } \\
5 \text { reports the second-stage regressi } \\
\text { industry-year mean is not biased to } \\
\text { statistics are based on robust stand } \\
\text { respectively. }\end{array}$ & $\begin{array}{l}\text { system GMM } \\
\text { (CSR), and a du } \\
\text { Variable definiti } \\
\text { els to mitigate th } \\
\text { te two years bef } \\
\text { years (i.e., } H L E \\
\text { egression using } \\
\text { ons using the fit } \\
\text { award outliers, } \\
\text { ard errors adjus }\end{array}$ & $\begin{array}{l}\text { egression resul } \\
\text { mmy variable e } \\
\text { ons are provide } \\
\text { e influence of o } \\
\text { re the base yea } \\
V_{t-3} \text { and } H L E V_{t} \\
\text { the fitted value } \\
\text { ted values of } C \\
\text { e require that } \mathrm{e} \\
\text { ed for clusterin }\end{array}$ & $\begin{array}{l}\text { s. The depende } \\
\text { qual to } 1 \text { if the } \\
\text { d in Appendix } \\
\text { utliers. We use } \\
\text {, and } 0 \text { otherw } \\
\text { 4) in the spirit c } \\
\text { of } H L E V \text {. Mo } \\
R, H L E V \text {, and } \\
\text { ach industry-ye } \\
\text { at the firm ley }\end{array}$ & $\begin{array}{l}\text { nt variable is i } \\
\text { firm's long-ter } \\
3 \text {. All the cont } \\
\text { two instrumen } \\
\text { ise, and 2) CSI } \\
\text { f Campello (2 } \\
\text { del } 4 \text { reports th } \\
C S R \times H L E V \text {. I } \\
\text { ar contain at le } \\
\text { el. ***,**, an }\end{array}$ & $\begin{array}{l}\text { dustry-adjusted } \\
\text { a debt-to-assets } \\
1 \text { variables are a } \\
\left.\text { s for } C S R_{t-2}: 1\right) \\
-3 \text {, the one-year } \\
\text { 03). The first-st } \\
\text { second-stage re } \\
\text { odels } 6 \text { to } 8 \text { repo } \\
\text { st four firms. Tl } \\
* \text { denote statist }\end{array}$ & $\begin{array}{l}\text { growth } \\
\text { is in the } \\
\text { ted to th } \\
E_{t-2} \text { an it } \\
\text { ed } C S R_{t-2} \\
\text { egressio } \\
\text { sions usi } \\
\text { le system } \\
\text { imple pe } \\
\text { significa }\end{array}$ & $\begin{array}{l}\left.S \_G\right) \text { Th } \\
\text { ree decile } \\
\text { ustry-yea } \\
\text { r equal to } \\
\text { strument } \\
\text { reported i } \\
\text { fitted val } \\
\text { I results. } \\
1996-201 \\
\text { the } 1 \%, 5\end{array}$ & $\begin{array}{l}\text { in variables of } \\
\text { the overall } \\
\text { ans, and are } \\
\text { a firm is } \\
H L E V_{t-2} \text {, we use } \\
\text { odels } 1 \text { and } 2 \text {. } \\
\text { of CSR. Model } \\
\text { nsure that the } \\
\text { he reported } t \text { - } \\
\text { nd } 10 \% \text { levels, }\end{array}$ \\
\hline
\end{tabular}




\section{CONSTANT}

Notes: This table reports the results for the effect of CSR on the costs of high leverage during the financial crisis using a firm fixed-effect model. The dependent variable is industry-adjusted sales growth (SALES_G). The main variables of interest are industry-adjusted CSR (CSR), and a dummy variable equal to 1 if the firm's long-term debtto-assets ratio is in the top three deciles of the overall sample in the given year (HLEV). We follow Lins et al. (2013), and define 2008 and 2009 as the financial crisis period (FINANCIAL CRISIS). Variable definitions are provided in Appendix B. All the control variables are adjusted to their industry-year means, and are winsorized at the $1 \%$ and $99 \%$ levels to mitigate the influence of outliers. To ensure that the industry-year mean is not biased toward outliers, we require that each industry-year contain at least four firms. The sample period is 1996-2012. The reported $t$-statistics are based on robust standard errors adjusted for clustering at the firm level. ***, **, and * denote statistical significance at the $1 \%, 5 \%$, and $10 \%$ levels, respectively. 
Table 8. CSR and the costs of high leverage: Customer channel

\begin{tabular}{|c|c|c|c|c|c|c|}
\hline & \multicolumn{2}{|c|}{ Firm R\&D Intensity } & \multicolumn{2}{|c|}{ Product Differentiation } & \multicolumn{2}{|c|}{ Customer Sensitivity } \\
\hline & High & Low & $\begin{array}{c}\text { Service or } \\
\text { Differentiated }\end{array}$ & Standardized & High & Low \\
\hline & (1) & (2) & (3) & (4) & (5) & (6) \\
\hline$C S R_{t-2} \times H L E V_{t-2}$ & $\begin{array}{c}0.035^{* * *} \\
(3.52)\end{array}$ & $\begin{array}{l}-0.003 \\
(-0.20)\end{array}$ & $\begin{array}{c}0.032 * * * \\
(2.86)\end{array}$ & $\begin{array}{r}0.010 \\
(0.88)\end{array}$ & $\begin{array}{c}0.029 * * * \\
(3.16)\end{array}$ & $\begin{array}{r}0.007 \\
(0.51)\end{array}$ \\
\hline$H L E V_{t-2}$ & $\begin{array}{c}-0.013 * * \\
(-2.23)\end{array}$ & $\begin{array}{c}-0.042 * * * \\
(-4.48)\end{array}$ & $\begin{array}{c}-0.017 * * \\
(-2.40)\end{array}$ & $\begin{array}{l}-0.017 * \\
(-1.73)\end{array}$ & $\begin{array}{c}-0.023 * * * \\
(-3.28)\end{array}$ & $\begin{array}{c}-0.028 * * * \\
(-3.07)\end{array}$ \\
\hline$C S R_{t-2}$ & $\begin{array}{c}-0.020 * * * \\
(-3.16)\end{array}$ & $\begin{array}{r}0.001 \\
(0.16)\end{array}$ & $\begin{array}{r}-0.010 \\
(-1.29)\end{array}$ & $\begin{array}{l}-0.013 \\
(-1.35)\end{array}$ & $\begin{array}{r}-0.007 \\
(-1.10)\end{array}$ & $\begin{array}{l}-0.019^{*} \\
(-1.95)\end{array}$ \\
\hline$S_{Z I Z E_{t}}$ & $\begin{array}{c}0.011 * * * \\
(4.32)\end{array}$ & $\begin{array}{c}0.050 * * * \\
(5.25)\end{array}$ & $\begin{array}{c}0.051 * * * \\
(6.56)\end{array}$ & $\begin{array}{l}0.029 * * \\
(2.30)\end{array}$ & $\begin{array}{c}0.042 * * * \\
(4.85)\end{array}$ & $\begin{array}{c}0.060 * * * \\
(6.05)\end{array}$ \\
\hline PROFIT $_{t-1}$ & $\begin{array}{r}0.021 \\
(0.79)\end{array}$ & $\begin{array}{r}-0.003 \\
(-0.07)\end{array}$ & $\begin{array}{r}-0.011 \\
(-0.44)\end{array}$ & $\begin{array}{l}-0.062 \\
(-0.78)\end{array}$ & $\begin{array}{r}0.030 \\
(0.78)\end{array}$ & $\begin{array}{l}-0.066^{* *} \\
(-1.96)\end{array}$ \\
\hline PROFIT $_{t-2}$ & $\begin{array}{r}0.022 \\
(0.84)\end{array}$ & $\begin{array}{l}-0.073^{*} \\
(-1.88)\end{array}$ & $\begin{array}{r}0.007 \\
(0.24)\end{array}$ & $\begin{array}{l}-0.068 \\
(-0.92)\end{array}$ & $\begin{array}{l}-0.044 \\
(-1.16)\end{array}$ & $\begin{array}{l}-0.015 \\
(-0.47)\end{array}$ \\
\hline$I_{N V E S T M E N T} T_{t-1}$ & $\begin{array}{l}-0.053 \\
(-0.39)\end{array}$ & $\begin{array}{r}0.151 \\
(1.29)\end{array}$ & $\begin{array}{c}-0.189 * * \\
(-2.14)\end{array}$ & $\begin{array}{r}-0.305 \\
(-1.54)\end{array}$ & $\begin{array}{r}0.061 \\
(0.62)\end{array}$ & $\begin{array}{c}-0.102 \\
(-0.77)\end{array}$ \\
\hline$I_{N V E S T M E N T} T_{t-2}$ & $\begin{array}{r}0.031 \\
(0.30)\end{array}$ & $\begin{array}{l}-0.125 \\
(-0.96)\end{array}$ & $\begin{array}{r}-0.005 \\
(-0.05)\end{array}$ & $\begin{array}{l}-0.399^{*} \\
(-1.71)\end{array}$ & $\begin{array}{r}-0.019 \\
(-0.14)\end{array}$ & $\begin{array}{l}-0.223^{*} \\
(-1.66)\end{array}$ \\
\hline$S E L L E X P_{t-1}$ & $\begin{array}{c}0.043 * * * \\
(2.71)\end{array}$ & $\begin{array}{c}-0.122 * * * \\
(-3.72)\end{array}$ & $\begin{array}{c}0.072 * * * \\
(4.32)\end{array}$ & $\begin{array}{c}0.086^{* * * *} \\
(3.29)\end{array}$ & $\begin{array}{c}0.105 * * * \\
(5.32)\end{array}$ & $\begin{array}{c}-0.032 \\
(-1.30)\end{array}$ \\
\hline$S E L L E X P_{t-2}$ & $\begin{array}{r}0.011 \\
(0.55)\end{array}$ & $\begin{array}{r}0.036 \\
(1.08)\end{array}$ & $\begin{array}{c}0.068^{* *} \\
(2.22)\end{array}$ & $\begin{array}{c}0.028 \\
(0.87)\end{array}$ & $\begin{array}{c}0.032 \\
(1.30)\end{array}$ & $\begin{array}{l}0.056^{*} \\
(1.95)\end{array}$ \\
\hline CONSTANT & $\begin{array}{c}-0.016 * * \\
(-2.23)\end{array}$ & $\begin{array}{c}-0.082 * * * \\
(-5.25)\end{array}$ & $\begin{array}{c}-0.065^{* * *} \\
(-4.59)\end{array}$ & $\begin{array}{c}0.004 \\
(0.15)\end{array}$ & $\begin{array}{c}-0.041 * * * \\
(-2.73)\end{array}$ & $\begin{array}{c}-0.092 * * * \\
(-4.24)\end{array}$ \\
\hline $\mathrm{N}$ & 8,653 & 7,737 & 10,969 & 3,267 & 7,520 & 8,870 \\
\hline R-squared & 0.026 & 0.022 & 0.023 & 0.062 & 0.046 & 0.015 \\
\hline
\end{tabular}

Notes: This table reports the results from re-running our analysis on the effects of CSR on high leverage costs using subsamples split by characteristics related to customer-driven costs of high leverage. All regressions include firm-fixed effects. The dependent variable is industry-adjusted sales growth (SALES_G). The main variables of interest are industry-adjusted CSR and $H L E V$, a dummy variable equal to 1 if the firm's long-term debt-to-assets ratio is in the top three deciles of the overall sample in the given year. Variable definitions are provided in Appendix B. All the control variables are adjusted to their industry-year means, and are 
winsorized at the $1 \%$ and $99 \%$ levels to mitigate the influence of outliers. In Models 1 and 2 , we proxy for the degree of product specialization using R\&D expenditures. A firm is classified as a high- (low-) R\&D intensity firm in a given year if its R\&D-to-sales ratio is greater (smaller) than $0.1 \%$ two years before the base year (Opler and Titman, 1994). In Models 3 and 4, services or differentiated (standardized) refers to industries that produce services or differentiated (standardized) products. Following Giannetti et al. (2011) and Rauch (1999), industries with differentiated goods or services have two-digit SIC codes: 25, 27, 30, $32,34,35,36,37,38$, and 39, while industries with standardized goods or services have two-digit SIC codes: 12, 14, 20, 22, 23, 24, 26, 28, 29, 31, 33, 41, 42, 44, $45,47,48,49,50,51,52,53,54,55,56,57,59,61,64,65,73,75,78$, and 79. In Models 5 and 6, high (low) customer sensitivity refers to industries in which the predominant customer is a consumer (industrial buyer). Following Lev et al. (2010), high-customer sensitivity industries have SIC code ranges: [0,999], [2000,2399], [2500,2599], [2700,2799], [2830,2869], [3000,3219], [3420,3429], 3523, [3600,3669], [3700,3719], 3751, [3850,3879], [3880,3999], 4813, [4830,4899], [5000,5079], [5090,5099], [5130,5159], [5220,5999], [6000,6999], [7000,7299], and [7400,9999]; the remaining industries are defined as low-customer sensitivity industries. To ensure that the industry-year mean is not biased toward outliers, we require that each industry-year contain at least four firms. The sample period is 1996-2012. The reported $t$-statistics are based on robust standard errors adjusted for clustering at the firm level. ***,**, and $*$ denote statistical significance at the $1 \%, 5 \%$, and $10 \%$ levels, respectively. 
Table 9. CSR and the costs of high leverage: Competitor channel

\begin{tabular}{|c|c|c|c|c|c|c|}
\hline & \multicolumn{2}{|c|}{$\underline{\text { Industry Debt Level }}$} & \multicolumn{2}{|c|}{ Industry Concentration $(F F C)$} & \multicolumn{2}{|c|}{ Industry Concentration $(H H I)$} \\
\hline & Low & High & High & Low & High & Low \\
\hline & $(1)$ & $(2)$ & (3) & $(4)$ & $(5)$ & $(6)$ \\
\hline$C S R_{t-2} \times H L E V_{t-2}$ & $\begin{array}{c}0.035^{* * *} \\
(2.60)\end{array}$ & $\begin{array}{r}0.010 \\
(0.86)\end{array}$ & $\begin{array}{c}0.022 * * * \\
(2.67)\end{array}$ & $\begin{array}{r}0.031 \\
(0.73)\end{array}$ & $\begin{array}{l}0.019^{*} \\
(1.73)\end{array}$ & $\begin{array}{r}0.015 \\
(1.11)\end{array}$ \\
\hline$H L E V_{t-2}$ & $\begin{array}{l}-0.011 \\
(-1.16)\end{array}$ & $\begin{array}{c}-0.041^{* * *} \\
(-5.07)\end{array}$ & $\begin{array}{c}-0.027 * * * \\
(-4.47)\end{array}$ & $\begin{array}{r}0.013 \\
(0.44)\end{array}$ & $\begin{array}{c}-0.038^{* * *} \\
(-4.23)\end{array}$ & $\begin{array}{c}-0.021^{* *} \\
(-2.52)\end{array}$ \\
\hline $\operatorname{CSR}_{t-2}$ & $\begin{array}{c}-0.019 * * \\
(-2.55)\end{array}$ & $\begin{array}{l}-0.006 \\
(-0.68)\end{array}$ & $\begin{array}{c}-0.017 * * * \\
(-2.76)\end{array}$ & $\begin{array}{l}-0.008 \\
(-0.39)\end{array}$ & $\begin{array}{c}-0.022^{* * *} \\
(-2.90)\end{array}$ & $\begin{array}{r}-0.005 \\
(-0.53)\end{array}$ \\
\hline$S I Z E_{t}$ & $\begin{array}{c}0.056^{* * * *} \\
(5.65)\end{array}$ & $\begin{array}{c}0.049^{* * *} \\
(5.50)\end{array}$ & $\begin{array}{c}0.050^{* * *} \\
(7.45)\end{array}$ & $\begin{array}{r}0.063 \\
(1.62)\end{array}$ & $\begin{array}{c}0.061 * * * \\
(6.10)\end{array}$ & $\begin{array}{c}0.063^{* * * *} \\
(6.89)\end{array}$ \\
\hline PROFIT $_{t-1}$ & $\begin{array}{r}-0.035 \\
(-1.13)\end{array}$ & $\begin{array}{r}-0.065 \\
(-1.51)\end{array}$ & $\begin{array}{r}-0.022 \\
(-0.85)\end{array}$ & $\begin{array}{l}-0.067 \\
(-1.08)\end{array}$ & $\begin{array}{c}-0.086^{* *} \\
(-2.03)\end{array}$ & $\begin{array}{r}-0.011 \\
(-0.41)\end{array}$ \\
\hline$P_{R O F I T}{ }_{t-2}$ & $\begin{array}{r}0.015 \\
(0.54)\end{array}$ & $\begin{array}{c}-0.137 * * * \\
(-3.17)\end{array}$ & $\begin{array}{l}-0.018 \\
(-0.69)\end{array}$ & $\begin{array}{r}0.049 \\
(0.63)\end{array}$ & $\begin{array}{c}-0.132 * * * \\
(-3.45)\end{array}$ & $\begin{array}{c}0.091 * * * \\
(3.63)\end{array}$ \\
\hline$I_{N V E S T M E N T} T_{t-1}$ & $\begin{array}{c}-0.308 * * \\
(-2.46)\end{array}$ & $\begin{array}{r}0.118 \\
(0.96)\end{array}$ & $\begin{array}{l}-0.025 \\
(-0.26)\end{array}$ & $\begin{array}{l}-0.206 \\
(-0.73)\end{array}$ & $\begin{array}{r}0.145 \\
(0.95)\end{array}$ & $\begin{array}{c}-0.250 * * * \\
(-2.63)\end{array}$ \\
\hline$I_{N V E S T M E N T} T_{t-2}$ & $\begin{array}{l}-0.104 \\
(-0.84)\end{array}$ & $\begin{array}{l}-0.154 \\
(-1.13)\end{array}$ & $\begin{array}{l}-0.130 \\
(-1.27)\end{array}$ & $\begin{array}{r}0.233 \\
(0.85)\end{array}$ & $\begin{array}{l}-0.241 \\
(-1.53)\end{array}$ & $\begin{array}{r}0.056 \\
(0.48)\end{array}$ \\
\hline$S E L L E X P_{t-1}$ & $\begin{array}{c}0.089 * * * \\
(4.74)\end{array}$ & $\begin{array}{c}-0.125 * * * \\
(-4.44)\end{array}$ & $\begin{array}{c}0.040 * * \\
(2.57)\end{array}$ & $\begin{array}{c}0.415^{* * * *} \\
(3.38)\end{array}$ & $\begin{array}{l}0.036^{*} \\
(1.66)\end{array}$ & $\begin{array}{c}0.045^{* * * *} \\
(2.62)\end{array}$ \\
\hline$S E L L E X P_{t-2}$ & $\begin{array}{l}0.058^{* *} \\
(2.41)\end{array}$ & $\begin{array}{r}0.006 \\
(0.24)\end{array}$ & $\begin{array}{c}0.050^{* *} \\
(2.34)\end{array}$ & $\begin{array}{c}0.510^{* * * *} \\
(3.54)\end{array}$ & $\begin{array}{r}0.029 \\
(1.16)\end{array}$ & $\begin{array}{c}0.116^{* * *} \\
(4.46)\end{array}$ \\
\hline CONSTANT & $\begin{array}{c}-0.063 * * * \\
(-3.28)\end{array}$ & $\begin{array}{c}-0.078^{* * *} \\
(-4.63)\end{array}$ & $\begin{array}{c}-0.060 * * * \\
(-4.47)\end{array}$ & $\begin{array}{r}0.103 \\
(1.08)\end{array}$ & $\begin{array}{c}-0.040 * * \\
(-2.22)\end{array}$ & $\begin{array}{c}-0.104 * * * \\
(-5.55)\end{array}$ \\
\hline$N$ & 8,823 & 7,567 & 15,260 & 1,130 & 8,175 & 8,215 \\
\hline$R$-squared & 0.043 & 0.022 & 0.019 & 0.085 & 0.027 & 0.029 \\
\hline
\end{tabular}

Notes: This table reports the results from re-running our analysis on the effects of CSR on high leverage costs using subsamples split by characteristics related to the competitor-driven costs of high leverage. All regressions include firm-fixed effects. The dependent variable is industry-adjusted sales growth (SALES_G). The main variables of interest are industry-adjusted $C S R$ and $H L E V$, a dummy variable equal to 1 if the firm's long-term debt-to-assets ratio is in the top three deciles of the overall sample in the given year. Variable definitions are provided in Appendix B. All of the control variables are adjusted to their industry-year means and are winsorized at the $1 \%$ and $99 \%$ levels to mitigate the influence of outliers. In Models 1 and 2, we proxy for the financial condition of a firm's competitors using 
the industry-average debt level: An industry is classified as a high- (low-) debt industry in a given year if its average long-term debt ratio is above (below) the median of the overall sample two years before the base year (Campello, 2003; Campello and Fluck, 2006). In Models 3 and 4, we classify an industry as highly (less) concentrated if its four-firm concentration ratio is above (below) 40\% the overall sample median two years before the base year (Opler and Titman, 1994). In Models 5 and 6, we classify an industry as highly (less) concentrated if its HHI is above (below) the overall sample median two years before the base year. To ensure that the industry-year mean is not biased toward outliers, we require that each industry-year contain at least four firms. The sample period is $1996-2012$. The reported $t$-statistics are based on robust standard errors adjusted for clustering at the firm level. ***,**, and * denote statistical significance at the $1 \%, 5 \%$, and $10 \%$ levels, respectively. 
Table 10. CSR and the costs of high leverage: The role of losses

\begin{tabular}{|c|c|}
\hline & (1) \\
\hline$L O S S_{t-2} \times C S R_{t-2} \times H L E V_{t-2}$ & $\begin{array}{l}0.121^{* *} \\
(2.18)\end{array}$ \\
\hline$C S R_{t-2} \times H L E V_{t-2}$ & $\begin{array}{l}0.018^{*} \\
(1.80)\end{array}$ \\
\hline$L O S S_{t-2} \times C S R_{t-2}$ & $\begin{array}{r}0.009 \\
(0.38)\end{array}$ \\
\hline$L O S S_{t-2} \times H L E V_{t-2}$ & $\begin{array}{c}0.028 \\
(1.34)\end{array}$ \\
\hline$C S R_{t-2}$ & $\begin{array}{l}-0.015^{* *} \\
(-2.47)\end{array}$ \\
\hline$H L E V_{t-2}$ & $\begin{array}{l}-0.028 * * * \\
(-5.05)\end{array}$ \\
\hline$L O S S_{t-2}$ & $\begin{array}{l}-0.153^{* * *} \\
(-14.92)\end{array}$ \\
\hline$S_{Z I Z E_{t}}$ & $\begin{array}{l}0.045^{* * *} \\
(9.71)\end{array}$ \\
\hline PROFIT $_{t-1}$ & $\begin{array}{l}-0.046^{* * *} \\
(-2.77)\end{array}$ \\
\hline PROFIT $_{t-2}$ & $\begin{array}{r}-0.019 \\
(-1.20)\end{array}$ \\
\hline INVESTMENT $_{t-1}$ & $\begin{array}{l}-0.028 \\
(-0.44)\end{array}$ \\
\hline$I_{N V E S T M E N T} T_{t-2}$ & $\begin{array}{l}-0.140 * * \\
(-2.30)\end{array}$ \\
\hline$S E L L E X P_{t-1}$ & $\begin{array}{l}0.041^{* * *} \\
(4.65)\end{array}$ \\
\hline$S E L L E X P_{t-2}$ & $\begin{array}{l}0.051^{* * *} \\
(5.95)\end{array}$ \\
\hline CONSTANT & $\begin{array}{l}-0.036 \text { *** } \\
(-4.00)\end{array}$ \\
\hline$N$ & 16,381 \\
\hline$R$-squared & 0.038 \\
\hline
\end{tabular}

Notes: This table reports the results for the effect of CSR on the costs of high leverage for loss-making firms using a firm fixed-effect model. The dependent variable is industry-adjusted sales growth (SALES_G). The main variables of interest are industry-adjusted CSR (CSR), and a dummy variable equal to 1 if the firm's long-term debt-to-assets ratio is in the top three deciles of the overall sample in the given year (HLEV). LOSS is a dummy variable equal to 1 if a firm experiences negative earnings before interest and taxes in a given year. Variable definitions are provided in Appendix B. All the control variables are adjusted to their industry-year means, and are winsorized at the $1 \%$ and $99 \%$ levels to mitigate the influence of outliers. To ensure that the industry-year mean is not biased toward outliers, we require that each industry-year contain at least four firms. The sample period is 1996-2012. The reported $t$-statistics are based on robust standard errors adjusted for clustering at the firm level. ***,**, and * denote statistical significance at the $1 \%, 5 \%$, and $10 \%$ levels, respectively. 
Table 11. CSR components and the costs of high leverage

\begin{tabular}{|c|c|c|c|c|c|c|}
\hline & Community & Diversity & $\begin{array}{c}\text { Employee } \\
\text { relations }\end{array}$ & Environment & Human rights & $\begin{array}{c}\text { Product } \\
\text { characteristics }\end{array}$ \\
\hline & (1) & (2) & (3) & (4) & (5) & (6) \\
\hline $\begin{array}{l}\text { CSR COMPONENT } T_{t-2} \times \\
H L E V_{t-2}\end{array}$ & $\begin{array}{c}0.042 \\
(1.48)\end{array}$ & $\begin{array}{r}0.012 \\
(0.79)\end{array}$ & $\begin{array}{r}0.025 \\
(1.15)\end{array}$ & $\begin{array}{l}0.067 * * \\
(2.35)\end{array}$ & $\begin{array}{r}0.023 \\
(0.56)\end{array}$ & $\begin{array}{l}0.058 * * * \\
(2.67)\end{array}$ \\
\hline$H L E V_{t-2}$ & $\begin{array}{l}-0.017 * * * \\
(-3.66)\end{array}$ & $\begin{array}{l}-0.018^{* * *} \\
(-3.85)\end{array}$ & $\begin{array}{l}-0.017 * * * \\
(-3.59)\end{array}$ & $\begin{array}{l}-0.017 * * * \\
(-3.68)\end{array}$ & $\begin{array}{l}-0.017 * * * \\
(-3.67)\end{array}$ & $\begin{array}{l}-0.016^{* * *} \\
(-3.53)\end{array}$ \\
\hline CSR COMPONENT $T_{t-2}$ & $\begin{array}{l}-0.013 \\
(-0.68)\end{array}$ & $\begin{array}{l}-0.046^{* * * *} \\
(-5.08)\end{array}$ & $\begin{array}{l}-0.000 \\
(-0.03)\end{array}$ & $\begin{array}{l}-0.036^{* *} \\
(-1.98)\end{array}$ & $\begin{array}{c}0.014 \\
(0.51)\end{array}$ & $\begin{array}{r}0.011 \\
(0.81)\end{array}$ \\
\hline $\operatorname{SIZE}_{t}$ & $\begin{array}{l}0.003 * \\
(1.78)\end{array}$ & $\begin{array}{l}0.005^{* * *} \\
(3.20)\end{array}$ & $\begin{array}{l}0.003 * \\
(1.79)\end{array}$ & $\begin{array}{l}0.003^{*} \\
(1.82)\end{array}$ & $\begin{array}{l}0.003^{*} \\
(1.83)\end{array}$ & $\begin{array}{l}0.003 * * \\
(2.08)\end{array}$ \\
\hline PROFIT $_{t-1}$ & $\begin{array}{l}0.066^{* * * *} \\
(2.68)\end{array}$ & $\begin{array}{l}0.065^{* * *} \\
(2.62)\end{array}$ & $\begin{array}{l}0.066^{* * * *} \\
(2.65)\end{array}$ & $\begin{array}{l}0.067 * * * \\
(2.68)\end{array}$ & $\begin{array}{l}0.066^{* * * *} \\
(2.66)\end{array}$ & $\begin{array}{l}0.065^{* * *} \\
(2.62)\end{array}$ \\
\hline PROFIT $_{t-2}$ & $\begin{array}{l}-0.018 \\
(-0.63)\end{array}$ & $\begin{array}{l}-0.020 \\
(-0.69)\end{array}$ & $\begin{array}{l}-0.019 \\
(-0.65)\end{array}$ & $\begin{array}{l}-0.018 \\
(-0.62)\end{array}$ & $\begin{array}{l}-0.019 \\
(-0.65)\end{array}$ & $\begin{array}{l}-0.021 \\
(-0.70)\end{array}$ \\
\hline INVESTMENT $T_{t-1}$ & $\begin{array}{l}0.223 * * \\
(2.34)\end{array}$ & $\begin{array}{l}0.225^{* *} \\
(2.36)\end{array}$ & $\begin{array}{l}0.223 * * \\
(2.33)\end{array}$ & $\begin{array}{l}0.226^{* *} \\
(2.38)\end{array}$ & $\begin{array}{l}0.223 * * \\
(2.34)\end{array}$ & $\begin{array}{l}0.221 * * \\
(2.31)\end{array}$ \\
\hline$I_{N V E S T M E N T} T_{t-2}$ & $\begin{array}{r}0.150 \\
(1.61)\end{array}$ & $\begin{array}{r}0.153 \\
(1.64)\end{array}$ & $\begin{array}{r}0.148 \\
(1.59)\end{array}$ & $\begin{array}{r}0.152 \\
(1.64)\end{array}$ & $\begin{array}{r}0.149 \\
(1.60)\end{array}$ & $\begin{array}{l}0.146 \\
(1.57)\end{array}$ \\
\hline$S E L L E X P_{t-1}$ & $\begin{array}{l}-0.014 \\
(-0.76)\end{array}$ & $\begin{array}{l}-0.014 \\
(-0.73)\end{array}$ & $\begin{array}{l}-0.014 \\
(-0.76)\end{array}$ & $\begin{array}{l}-0.014 \\
(-0.75)\end{array}$ & $\begin{array}{l}-0.014 \\
(-0.75)\end{array}$ & $\begin{array}{c}-0.014 \\
(-0.75)\end{array}$ \\
\hline$S E L L E X P_{t-2}$ & $\begin{array}{l}0.045^{* *} \\
(2.18)\end{array}$ & $\begin{array}{l}0.046^{* *} \\
(2.23)\end{array}$ & $\begin{array}{l}0.045^{* *} \\
(2.16)\end{array}$ & $\begin{array}{l}0.045^{* *} \\
(2.19)\end{array}$ & $\begin{array}{l}0.045^{* *} \\
(2.16)\end{array}$ & $\begin{array}{l}0.045^{* *} \\
(2.16)\end{array}$ \\
\hline CONSTANT & $\begin{array}{l}-0.011^{* *} \\
(-2.48)\end{array}$ & $\begin{array}{l}-0.014 * * * \\
(-3.19)\end{array}$ & $\begin{array}{l}-0.010^{* *} \\
(-2.46)\end{array}$ & $\begin{array}{l}-0.011^{* *} \\
(-2.49)\end{array}$ & $\begin{array}{l}-0.011^{* *} \\
(-2.49)\end{array}$ & $\begin{array}{l}-0.011^{* * *} \\
(-2.62)\end{array}$ \\
\hline$N$ & 16,390 & 16,390 & 16,390 & 16,390 & 16,390 & 16,390 \\
\hline$R$-squared & 0.013 & 0.015 & 0.013 & 0.013 & 0.013 & 0.014 \\
\hline
\end{tabular}

Notes: This table reports the effect of CSR components on the costs of high leverage using a firm fixed-effect model. The dependent variable is industry-adjusted sales growth (SALES_G). The main variables of interest are the industry-adjusted CSR components: community, diversity, employee relations, environment, human rights, and product characteristics (CSR COMPONENT), and a dummy variable equal to 1 if the firm's long-term debt-to-assets ratio is in the top three deciles of the overall sample in a given year $(H L E V)$. Variable definitions are provided in Appendix B. All the control variables are adjusted to their industry-year means, and are winsorized at the $1 \%$ and $99 \%$ levels to mitigate the influence of outliers. To ensure that the industry-year mean is not biased toward outliers, we require 
that each industry-year contain at least four firms. The sample period is 1996-2012. The reported $t$-statistics are based on robust standard errors adjusted for clustering at the firm level. $* * *, * *$, and $*$ denote statistical significance at the $1 \%, 5 \%$, and $10 \%$ levels, respectively. 
Table 12. Robustness checks: Alternative measures

\begin{tabular}{|c|c|c|c|c|c|c|c|c|c|c|c|}
\hline & \multicolumn{6}{|c|}{$H L E V_{t-2}$} & \multicolumn{4}{|c|}{$C S R_{t-2}$} & \multirow{3}{*}{$\begin{array}{c}\text { Dep. Var } \\
\begin{array}{c}\text { Market Share } \\
\text { Growth }\end{array} \\
(11)\end{array}$} \\
\hline & \multicolumn{2}{|c|}{ Top Decile } & \multicolumn{2}{|c|}{ Total Debt } & \multicolumn{2}{|c|}{ Lag 3 Years } & \multirow{2}{*}{$\frac{C S R_{-} N E T_{t-2}}{(7)}$} & \multirow{2}{*}{$\begin{array}{c}\text { Adjusted CSR } \\
(8) \\
\end{array}$} & \multirow{2}{*}{$\begin{array}{c}\text { PCA } \\
(9) \\
\end{array}$} & \multirow{2}{*}{$\begin{array}{c}\text { Add CGOV } \\
(10) \\
\end{array}$} & \\
\hline & $(1)$ & $(2)$ & (3) & $(4)$ & $(5)$ & $(6)$ & & & & & \\
\hline$C S R_{t-2} \times H L E V_{t-2}$ & & $\begin{array}{c}0.068 * * * \\
(3.13)\end{array}$ & & $\begin{array}{c}0.019 * * \\
(2.09)\end{array}$ & & $\begin{array}{c}0.024 * * \\
(2.53)\end{array}$ & $\begin{array}{c}0.005 * * * \\
(2.65)\end{array}$ & $\begin{array}{l}0.021 * * * \\
(3.10)\end{array}$ & $\begin{array}{c}0.010 * * * \\
(2.73)\end{array}$ & $\begin{array}{c}0.021 * * * \\
(3.10)\end{array}$ & $\begin{array}{c}0.024 * * * \\
(3.57)\end{array}$ \\
\hline$H L E V_{t-2}$ & $\begin{array}{c}-0.036^{* * *} \\
(-3.42)\end{array}$ & $\begin{array}{c}-0.034 * * * \\
(-3.20)\end{array}$ & $\begin{array}{c}-0.028 * * * \\
(-3.99)\end{array}$ & $\begin{array}{c}-0.029 * * * \\
(-4.07)\end{array}$ & $\begin{array}{c}-0.010^{* *} \\
(-2.30)\end{array}$ & $\begin{array}{c}-0.010^{* *} \\
(-2.26)\end{array}$ & $\begin{array}{c}-0.026 * * * \\
(-4.41)\end{array}$ & $\begin{array}{c}-0.015 * * * \\
(-3.78)\end{array}$ & $\begin{array}{c}-0.021 * * * \\
(-3.17)\end{array}$ & $\begin{array}{c}-0.015^{* * *} \\
(-3.78)\end{array}$ & $\begin{array}{c}-0.015 * * * \\
(-3.95)\end{array}$ \\
\hline$C S R_{t-2}$ & & $\begin{array}{c}-0.029 * * \\
(-2.48)\end{array}$ & & $\begin{array}{c}-0.012 * * \\
(-2.25)\end{array}$ & & $\begin{array}{l}-0.009 \\
(-1.54)\end{array}$ & $\begin{array}{c}-0.003 * * \\
(-2.30)\end{array}$ & $\begin{array}{l}-0.007 \\
(-1.53)\end{array}$ & $\begin{array}{c}-0.007 * * * \\
(-2.61)\end{array}$ & $\begin{array}{l}-0.007 \\
(-1.53)\end{array}$ & $\begin{array}{c}-0.013 * * * \\
(-3.07)\end{array}$ \\
\hline$S I Z E_{t}$ & $\begin{array}{c}0.015^{* * *} \\
(3.98)\end{array}$ & $\begin{array}{c}0.016^{* * * *} \\
(4.22)\end{array}$ & $\begin{array}{c}0.050^{* * *} \\
(7.73)\end{array}$ & $\begin{array}{c}0.050^{* * *} \\
(7.69)\end{array}$ & $\begin{array}{l}0.000 \\
(0.18)\end{array}$ & $\begin{array}{l}0.000 \\
(0.32)\end{array}$ & $\begin{array}{c}0.051 * * * \\
(7.82)\end{array}$ & $\begin{array}{l}0.000 \\
(0.07)\end{array}$ & $\begin{array}{c}0.064 * * * \\
(8.95)\end{array}$ & $\begin{array}{l}0.000 \\
(0.07)\end{array}$ & $\begin{array}{c}0.004 * * * \\
(3.36)\end{array}$ \\
\hline PROFIT $_{t-1}$ & $\begin{array}{l}0.025 \\
(0.79)\end{array}$ & $\begin{array}{l}0.025 \\
(0.77)\end{array}$ & $\begin{array}{l}-0.020 \\
(-0.82)\end{array}$ & $\begin{array}{l}-0.020 \\
(-0.84)\end{array}$ & $\begin{array}{c}0.078^{* * * *} \\
(3.61)\end{array}$ & $\begin{array}{c}0.078 * * * \\
(3.61)\end{array}$ & $\begin{array}{l}-0.022 \\
(-0.91)\end{array}$ & $\begin{array}{c}0.064 * * * \\
(3.12)\end{array}$ & $\begin{array}{c}-0.053^{*} \\
(-1.93)\end{array}$ & $\begin{array}{c}0.064 * * * \\
(3.12)\end{array}$ & $\begin{array}{c}0.099 * * * \\
(4.95)\end{array}$ \\
\hline PROFIT $_{t-2}$ & $\begin{array}{l}0.008 \\
(0.23)\end{array}$ & $\begin{array}{l}0.007 \\
(0.22)\end{array}$ & $\begin{array}{l}-0.021 \\
(-0.86)\end{array}$ & $\begin{array}{l}-0.021 \\
(-0.88)\end{array}$ & $\begin{array}{l}-0.009 \\
(-0.37)\end{array}$ & $\begin{array}{l}-0.009 \\
(-0.36)\end{array}$ & $\begin{array}{l}-0.020 \\
(-0.83)\end{array}$ & $\begin{array}{l}-0.006 \\
(-0.28)\end{array}$ & $\begin{array}{c}-0.085 * * \\
(-2.56)\end{array}$ & $\begin{array}{l}-0.006 \\
(-0.28)\end{array}$ & $\begin{array}{l}-0.018 \\
(-0.81)\end{array}$ \\
\hline$I N V E S T M E N T_{t-1}$ & $\begin{array}{c}0.494 * * * \\
(2.98)\end{array}$ & $\begin{array}{c}0.491 * * * \\
(2.98)\end{array}$ & $\begin{array}{l}-0.020 \\
(-0.22)\end{array}$ & $\begin{array}{l}-0.021 \\
(-0.23)\end{array}$ & $\begin{array}{c}0.271 * * * \\
(2.89)\end{array}$ & $\begin{array}{c}0.272 * * * \\
(2.91)\end{array}$ & $\begin{array}{l}-0.024 \\
(-0.27)\end{array}$ & $\begin{array}{c}0.324 * * * \\
(3.77)\end{array}$ & $\begin{array}{l}-0.153 \\
(-1.40)\end{array}$ & $\begin{array}{c}0.324 * * * \\
(3.77)\end{array}$ & $\begin{array}{c}0.172 * * \\
(2.20)\end{array}$ \\
\hline$I_{N V E S T M E N T} T_{t-2}$ & $\begin{array}{l}0.035 \\
(0.21)\end{array}$ & $\begin{array}{l}0.043 \\
(0.25)\end{array}$ & $\begin{array}{l}-0.133 \\
(-1.36)\end{array}$ & $\begin{array}{l}-0.134 \\
(-1.36)\end{array}$ & $\begin{array}{l}0.125 \\
(1.45)\end{array}$ & $\begin{array}{l}0.127 \\
(1.47)\end{array}$ & $\begin{array}{l}-0.136 \\
(-1.38)\end{array}$ & $\begin{array}{l}0.111 \\
(1.38)\end{array}$ & $\begin{array}{l}-0.154 \\
(-1.38)\end{array}$ & $\begin{array}{l}0.111 \\
(1.38)\end{array}$ & $\begin{array}{l}0.105 \\
(1.54)\end{array}$ \\
\hline$S E L L E X P_{t-1}$ & $\begin{array}{l}0.001 \\
(0.03)\end{array}$ & $\begin{array}{l}0.001 \\
(0.02)\end{array}$ & $\begin{array}{c}0.040^{* * *} \\
(2.66)\end{array}$ & $\begin{array}{c}0.040 * * * \\
(2.66)\end{array}$ & $\begin{array}{c}-0.037 * * \\
(-2.47)\end{array}$ & $\begin{array}{c}-0.037 * * \\
(-2.45)\end{array}$ & $\begin{array}{c}0.040 * * * \\
(2.61)\end{array}$ & $\begin{array}{l}0.000 \\
(0.01)\end{array}$ & $\begin{array}{l}0.003 \\
(0.11)\end{array}$ & $\begin{array}{l}0.000 \\
(0.01)\end{array}$ & $\begin{array}{l}0.009 \\
(0.53)\end{array}$ \\
\hline$S E L L E X P_{t-2}$ & $\begin{array}{l}0.022 \\
(0.64)\end{array}$ & $\begin{array}{l}0.023 \\
(0.67)\end{array}$ & $\begin{array}{c}0.053 * * \\
(2.51)\end{array}$ & $\begin{array}{c}0.053^{* *} \\
(2.50)\end{array}$ & $\begin{array}{c}0.062 * * * \\
(3.74)\end{array}$ & $\begin{array}{c}0.062 * * * \\
(3.74)\end{array}$ & $\begin{array}{c}0.053 * * \\
(2.51)\end{array}$ & $\begin{array}{l}0.019 \\
(1.18)\end{array}$ & $\begin{array}{l}0.041 * \\
(1.65)\end{array}$ & $\begin{array}{l}0.019 \\
(1.18)\end{array}$ & $\begin{array}{c}0.035^{* *} \\
(2.04)\end{array}$ \\
\hline CONSTANT & $\begin{array}{l}-0.005 \\
(-0.58)\end{array}$ & $\begin{array}{l}-0.006 \\
(-0.70)\end{array}$ & $\begin{array}{c}-0.062 * * * \\
(-4.92)\end{array}$ & $\begin{array}{c}-0.061 * * * \\
(-4.85)\end{array}$ & $\begin{array}{c}-0.012 * * * \\
(-2.96)\end{array}$ & $\begin{array}{c}-0.012 * * * \\
(-2.98)\end{array}$ & $\begin{array}{c}-0.061 * * * \\
(-4.84)\end{array}$ & $\begin{array}{c}-0.009 * * \\
(-2.39)\end{array}$ & $\begin{array}{c}-0.100 * * * \\
(-6.31)\end{array}$ & $\begin{array}{c}-0.009 * * \\
(-2.39)\end{array}$ & $\begin{array}{l}-0.004 \\
(-0.94)\end{array}$ \\
\hline$N$ & 3,980 & 3,980 & 16,390 & 16,390 & 13,387 & 13,387 & 16,390 & 16,386 & 11,078 & 16,386 & 13,296 \\
\hline$R$-squared & 0.022 & 0.025 & 0.019 & 0.019 & 0.014 & 0.015 & 0.020 & 0.012 & 0.020 & 0.012 & 0.017 \\
\hline
\end{tabular}

Notes: This table reports the results for our main analyses on the costs of high leverage and the effect of CSR on the costs of high leverage using alternative definitions of $H L E V, C S R$, and SALES_G. All regressions include firm-fixed effects. The dependent variable is industry-adjusted sales growth (SALES_G). The main variables of interest are industry-adjusted CSR and $H L E V$, a dummy variable equal to 1 if the firm's long-term debt-to-assets ratio is in the top three deciles of the overall sample in the given year. Variable definitions are provided in Appendix B. All the control variables are adjusted to their industry-year means, and are winsorized at the $1 \%$ and $99 \%$ levels to mitigate the influence of outliers. Models 1 and 2 assign a value of 1 to top-decile firm-year observations and 0 to bottom-decile observations. Models 3 and 4 replace the long-term debt ratio with the total debt ratio. Models 5 and 6 lag both $C S R$ and $H L E V$ by three years to reflect the alternative definitions shown in Campello (2006). In Model 7, we use CSR_NET. In Model 8, we follow Jo and Harjoto (2012), and divide CSR_NET 
by the maximum number of strength and concern factors in the same year. Model 9 creates a comprehensive measure of CSR by adopting principal component analysis. In Model 10, CSR is computed based on all seven areas (including governance) in MSCI ESG STATS to facilitate comparison with other CSR studies (e.g., Deng et al., 2013). In Model 11, we replace the dependent variable sales growth (SALES_G) with market share growth. To ensure that the industry-year mean is not biased toward outliers, we require that each industry-year contain at least four firms. The sample period is 1996-2012. The reported $t$-statistics are based on robust standard errors adjusted for clustering at the firm level. ***,**, and * denote statistical significance at the $1 \%, 5 \%$, and $10 \%$ levels, respectively. 
Table 13. Robustness checks: Industry adjustment and alternative industry classifications

FIC-100

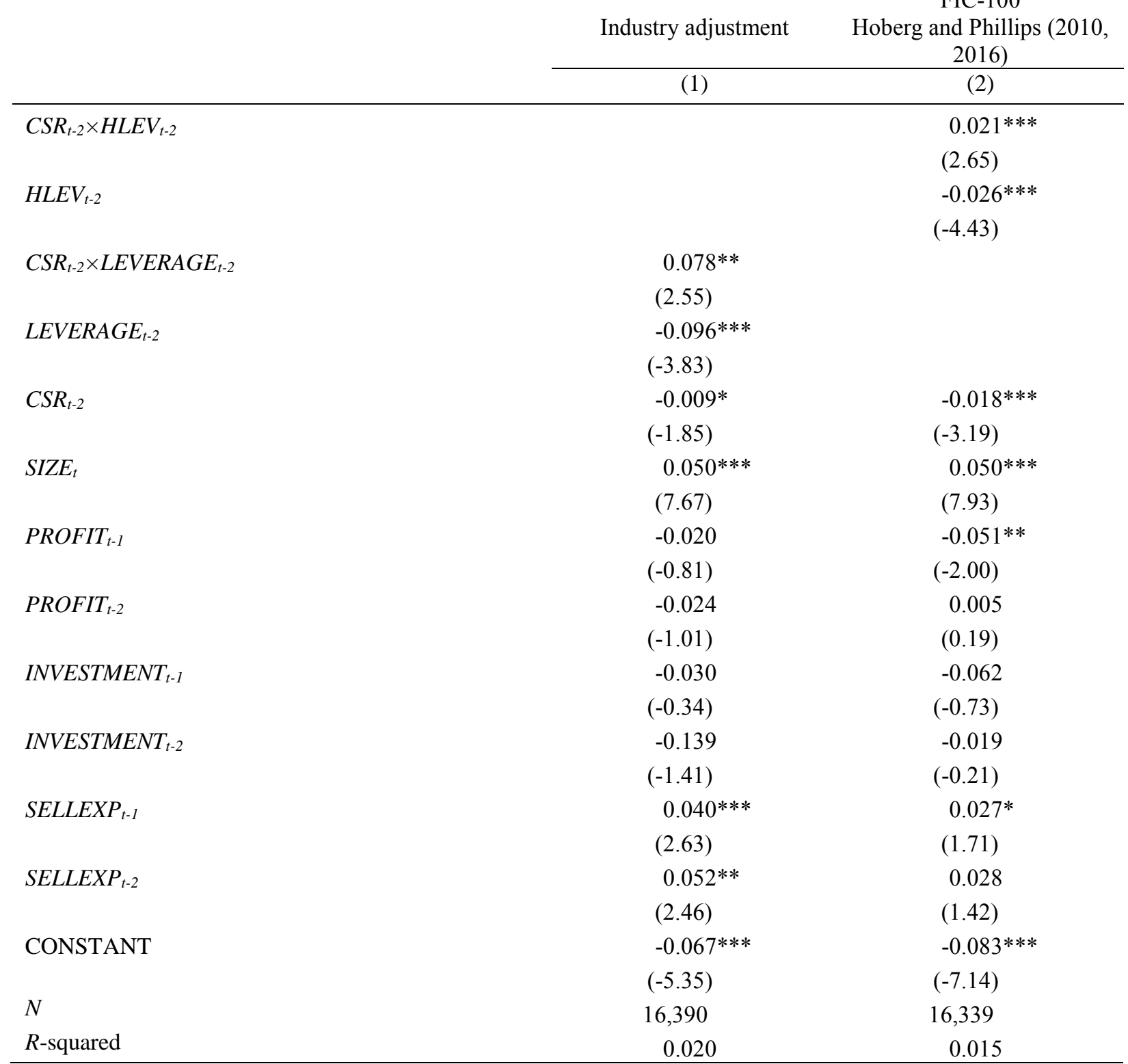

Notes: This table reports the effect of CSR on the costs of high leverage using a firm fixed-effect model. The dependent variable is industry-adjusted sales growth $\left(S A L E S \_G\right)$. The main variables of interest are industry-adjusted CSR and $H L E V$, a dummy variable equal to 1 if the firm's long-term debt-to-assets ratio is in the top three deciles of the overall sample in the given year. Variable definitions are provided in Appendix B. All the control variables are adjusted to their industry-year means, and are winsorized at the $1 \%$ and $99 \%$ levels to mitigate the influence of outliers. In Model 1 , we use a continuous leverage variable ( $L E V E R A G E)$ adjusted by subtracting its industry-year mean. In Model 2, we use an alternative industry classification, the 10-K Text-based Fixed Industry Classification (FIC-100) developed by Hoberg and Phillips $(2010,2016)$, instead of the Fama-French (1997) 48 -industry classification. To ensure that the industry-year mean is not biased toward outliers, we require that each industry-year contain at least four firms. The sample period is 1996-2012. The reported $t$-statistics are based on robust standard errors adjusted for clustering at the firm level. ***,**, and * denote statistical significance at the $1 \%, 5 \%$, and $10 \%$ levels, respectively. 